University of Louisville

ThinkIR: The University of Louisville's Institutional Repository

Electronic Theses and Dissertations

1933

\title{
The factors affecting the method of branching in Ailanthus glandulosa.
}

Emory W. Theiss

University of Louisville

Follow this and additional works at: https://ir.library.louisville.edu/etd

Part of the Botany Commons

\section{Recommended Citation}

Theiss, Emory W., "The factors affecting the method of branching in Ailanthus glandulosa." (1933). Electronic Theses and Dissertations. Paper 1947.

https://doi.org/10.18297/etd/1947

This Master's Thesis is brought to you for free and open access by ThinkIR: The University of Louisville's Institutional Repository. It has been accepted for inclusion in Electronic Theses and Dissertations by an authorized administrator of ThinkIR: The University of Louisville's Institutional Repository. This title appears here courtesy of the author, who has retained all other copyrights. For more information, please contact thinkir@louisville.edu. 
FACTORS AFFECTING THE METHOD OF BRANCHING IN AILANTHUS GLANDULOSA 
Unt versity of Lou1svilie

The Factors Affecting the Method of

Branching in Al lanthus Elanduloso

\author{
A Disiertation \\ Submitted to the Faculty \\ of the Graduate School of the University of Loulsville \\ In Partial Fulfillment of the \\ Requirements for the Degree \\ of Master of Science
}

Department of B1ology

By

Emory W. Theiss

1933 


\section{ACKNOWL EDG EMENT}

In highest appreciation of the generosity and kindness of Dr.

P. A. Davies, whose sympathetic

disection contributed to this study. 


\section{TABISE OF CONTENTS}

INTRODUCTION

PAGE

THE SPECIFIC PROBLFM

7

THE MATERIAL

8

TECHNIQUE

9

THE METHOD OF BRANCHING IN 1930 AND $1931 \quad 12$

THE INHERENT FACTORS AFFECTING BRANCHING 25

EXTERNAI FACTORS AFFEGTING BRANCHING 46

SUMMARY

69

CONCLUSION

63

LITERATURE CI TED

64 
INDEX TO FIGURES

\begin{tabular}{|c|c|}
\hline FIGURES & PAGE \\
\hline 1 & 22 \\
\hline 2 & 30 \\
\hline PLATES & PAGE \\
\hline$I$ & 18 \\
\hline II & 20 \\
\hline III & 23 \\
\hline IV & 29 \\
\hline V & 34 \\
\hline VI & 36 \\
\hline VII & 43 \\
\hline VIII & 45 \\
\hline IX & 54 \\
\hline$x$ & 56 \\
\hline$X I$ & 57 \\
\hline$X I I$ & 59 \\
\hline XIII & 60 \\
\hline TABLES & PAGE \\
\hline 1 & 14 \\
\hline 2 & 15 \\
\hline 3 & 27 \\
\hline 4 & 32 \\
\hline 5 & 41 \\
\hline 6 & 52 \\
\hline
\end{tabular}


INTRODUCTION

The method of branching in trees depends upon the development and growth of their buds. Most trees have a tendency to produce branches from their terminal or apical buds, while the more basal buds of the twigs remain dormant or die.

Li terature on factors affectine bud growth showe: (1) maturity of the bud and 1 ts supporting tissue, (2) nutrient condition of the supporting tis sue, (3) water conductive ab1lity of the sap-rood, and (4) dormancy as factors inherent in the plant. Avallable molsture, wound reaction, and climatic conditions are shown to be factors in the environment that affect growth in buds.

Bergen (2) states that woodj plants which have an indefinite annual growth continue to grow until their soft and immature tips are killed by frost. Growth of the shoot and its branches in the succeedine season is thereby restricted to the mature area of the shoot.

Gardner (14) shows a descending nitrogen-carbohydrate gradient correspondine with the growth of apical buds in the Bartlett pear. Harvey (15) shows a similar nutrient distribution corresponding to a similar growth of apical buds in the twigs of apple trees. Butler, Sm1th, and Curry (4) concur with Harvey in relating apical bud growth in the apple with the higher ratio of nitrogen adjacent to the growing buds. 
They attribute the aplcal bud growth to the upward translocation of nitrogen and the downward translocation of carbohydrates in the parent shoot. Davies (8) study of regeneration in Salix nigra likewise shows that the total cuantity of nitrogen in the shoot is distributed so that the bud growth takes place at the point of greatest nitrogen concentration. His results show that the initial changes prior to regeneration and development are not dependent upon the rapid translocation of nitrogen toward the area of bud growth. Denny and stanton (10) show that the reserve food in twiss of Syringa vulgaris is adequate and that renewal of growth in the buds was due to a factor w1 thin the buds.

The experiments of Farmer (12), Eustace (11), and Roberts (20) show a difference in the conductive ability of the wood in various shrubs and trees. The results of this difference in the conductive ability upon bud performance after dormancy have been construed differently by these workers. Eustace related the degree of bud fallure in the apical region of fruit tree twigs to the quantity of water contained and the ripeness of the wood. The greater the conductive ability of the wood in the apical recion of the shoot the ereater is the danger of frost injury to the buds. This view is at variance with the results shown in Farmer's experiments with youne ash and sycamore trees. The water conductive ability of the wood in the apices of the sycamore twigs was high and the apical growth was characteristically strong. Frost injury to the apical buds was absent. In the ash trees the 
conductive ability of the rood in the apices of the trigs was Ior; correspondingly frost injury was frequent in the apices of the twigs. Roberts' experimenta with cherries Ied him to conclude that climatic effects upon bud performance must be correlated with the stage of bud growth. The fruit bud in the cherry was killed by frost while the slower developInf leaves were often uninjured. It is therefore apparent that high, water conductive ability is related to strong and rapid growth of buds.

The existence of a dormant stage in the winter buds of perennials in the colder climates has long been acknowledged as a factor in bud growth. The cause of this dormancy as well as the renewal of growth after dormancy has not been determined. Loeb (19), from his work on Bxyophrlium calycinum, formulated the theory that the growing apex of a stem forms a definite inhibiting substance which mover toward the base and thereby Inhibits the growth of lateral buds. The work of Reed and Halm (21) with cuttings of Chinese lemon suspended in moist air, verifies Loeb's inhibition hypothesis. This theory is challenged by the results of an experiment on Byyophyllum calycinum conducted by Child and Bellamy (7). They found that 1 solation by means of low temperature did not impede the flor of fluids and substances in solution while it did block the inhibiting action of the growing tip. These results led them to conclude that the common phenomenon, dominance of the growing tip, was due to physiological activity of the cells within the dominant bud. The existence of an inhibiting substance in el ther the supporting or 
the bud cells is challenged by the experiments of Demy and stanton (9). They succesded in breaking the rest period. In 11lacs, crabapples, almonds, and snowballs by vapor stimulations of ethylene chlorhydrin, ethylene dichlorid, furfural, and prophylene chlorhydrin applied to the buds. The results of these experiments indicate that dormancy and the cause of 1 ts termination are important factors in determining bud development.

Horard (16) has shown that cut tw1gs of woody plants respond to treatmente that break the rest period in the same manner as pot-Grown plante if the cut ends are kept 1mmersed In water. The necessary avaliable water supply as a factor in bud growth is evident as Farmer (12) has shown for the sycamore, and Roberts (20) for the cherry.

Experiments show that wound reaction is a factor in abnormal bud growth. Coville (6) has shown that dormant buds of Lackintum corymbosum were forced to develop when portions of the stem adjacent to the bud was rubbed briskly with a knife handle. Ringing has produced a varlety of results. Barker and Lees (5) found that knife edge rings did not cause dormant buds of pear and other fruit trees to develop. Broader rings caused the buds below the rings to grow until a callus had formed over the ringed area. Summers (22) shows that the effects of pruning on twig development vary accordIng to the type of the plant. Pruned apple and pear shoots developed an acropetal pattern of bud growth similar to the unpruned shoots. Pruning to the last two or three buds 
upon the shoot produced negative regulto in all three. It is evident that accidental injury to buds or their adjacent ti ssues may cause abnormal bud growth in trees. It is further evident that in the event the injury is severe enough to cause the death of buds abnormal branching maj result.

As Roberts (20) has shown in his experiment with frost injury in cherries climatic factors must be considered in connection with the stage of bud growth. The experiments of Johanngen (17) w1th woody shrubs, and Coville (6) with Vaccinium corymbosum, show that uniformly low temperature during the dormant stage of the plant was conducive to an earlier spring growth than would have occurred in the absence of such chiling. Covilie shows that blueberry bushes kept at greenhouse temperatures were eight to fourteen days slower in developing their buds than those plants subjected to the Iow temperatures of winter out-of-doors. His experiments also show that bud failure in the terminal region of the plants kept in the greenhouse was frequent while out door plants exhiblted vigorous terminal growth. These experiments show that low temperature during the quiescent period of woody perennials in the colder climates is a factor in normal bud Growth after domancy. As previously stated from the results of Eustace's (11) and Wiggans' (23) experiments with fruit trees and Farmer's (12) experiment with sycamore and ash trees, Iow temperature after growth has actively begun in the buds is destmative to the buds and their supporting tissues. It is, therefore, evident that low temperature 
during the dormant stage is a stimulatine factor in bud growth but low temperature after the bud has begun act1 ve growth is a destructive factor in bud growth and consequently a factor that causes abnormal branching. 
THE SPECIFIC PROBLEM

Twigs or shoots of Allanthus glandulosa, Desf. (Tree of Heaven ) do not develop terminal buds. All elongation in the following season 1s, therefore, entirely dependent upon the development of axillary buds. As a solitary bud is developed in the axil of each leaf, the maximum potential branch development of each shoot is determined by the number of leaves developed upon the shoot in the previous season's growth. The number of leaves on shoots or twigs is not uniform. Keeler (18) states that the length of Al lanthus glandulosa shoots may vary from a few inches to more than five feet. The statement is too conservative; the writer has found shoots more than ten feet in length. Correspondingly, the number of leaves may vary from two to nearly fifty. It 1s, therefore, evident that the number of branches theoreticaliy possible may vary in the same proportion. It is a well known fact that all buds on the tree type plants do not develop into branches. Blakeslee and Jarvis (3) have shown that there is a struggle for existence among buds, and only a few succeed in developing into branches. It 18, therefore, evident that the number and position of buds that develop into branches determine the branch-patterns.

The purpose of this study is to determine (1) the number and position of axillary buds on shoots of Allanthus glandulosa that develop into branches, and (2) the factors principaliy responsible for the development of the buds. 
THE MATERIAL

A large thicket of uncul tivated Allanthus glandulosa served as an outdoor laboratory. It also supplied the cut shoots used in this experiment. The thicket is located on the banks of Silver Creek, Clark county, Indiana. 
TECHNIQUE

The number and the position of axtliary buds of uncultivated Allanthus glandulosa shoots that developed into branches was found in the following manner. In the spring of 1930 a sample of 225 young trees was selected at random. The number and the position of branches developed upon these trees nere tabulated ( Bee, Table 1, page 14). The tendencies in branching of this sample were then computed on the basis of the normal frequency curve as expounded by Garrett (13). In the apring of 1931 a second sample of branching was tabulated from 436 trees. The tendencies in branching were calculated on the same basis as used in the first sample ( 15). The collective results obtained from these two, annual, random, samples are considered fair examples of branch-patterns developed by Allanthus glandulosa.

The prinolpal factors responsible in affecting the branching were sought both within the tree and 1 ts environment. The relationship of those factors 1dentified $w 1$ th the nature of the plant ( flrst, maturity of the buds; second, food reserves; third, water conductivity; and fourth, dormancy) was measured by forcing bud growth in cut trigs. The influence of each of these factors upon potential branch development ras tested in the following manner.

1. The maturity of buds and their ab1lity to develop

Howard (16) has shown that cut trigs of moody plante reopond to treatment in the same manner as pot-grown plants. 
was tested by forcing both whole shoots and sections of ahoots into growth by placing their cut ends in battery jars containing tap water at room temperature.

2. The food reserves in the buds and their adjacent t1asues was tested by forolng growth in the tip sections contalning three buds. The forcing agents were molsture and room temperature.

3. The mater conductive ability of the tissues of shoots was tested by using common red ink in the water supply of the cuttings.

4. The existence of a dormant period and 1 ts influence upon bud development was tested by forcing buds into growth, by the molsture-temperature method, from the perlod of leaf fall until leaf development was reestablished in the following spring.

Effects of external factors ( first, avallable molsture; second, wound reactions; and third, low temperature) upon bud growth were tested in the following way.

1. The effect of avallable moisture upon bud growth was tested by comparing the development of cut twigs. Tro sets of outtings were kept at room temperature: the cutings of the first set were placed with their cut ends aubmerged in water, while the cuttings of the second set were kept without a rater supply. The latter set had their cut onds sealed of th surgical tape to prevent evaporation. 2. The effects of bruising, ringing, notching, and bending upon the behavior of buds in the cut shoots was compar- 
ed w1 th the bud development in cut twigs when both were Bubjected to the forcing treatments.

3. The effects of lon temperature upon bud performance was tested in two separate experiments. In the first experiment cut shoots were used. Freshly cut shoots with buds still domant and cuttings containing growing buds were frozen in a refrigerator for twenty-four hours and then subjected to the forcing tests. In the second experiment, the bud growth found in the thicket on March 1, 1932 was compared with the bud growth found upon trees In the thicket on April 16, 1932. A ten day period of sub-freezing temperature prevalled from the fifth to the fifteenth day of March. 
THE METHOD OF BRANCHING IN AILANTHUS GLANDULOSA AS SHOWN BY THE BRANCHING IN TWO SUCCESSIVE YEARS 
THE NUMBER OF BUDS THAT DEVELOPED INTO BRANCHES

The branches established by the random sample of two hundred twenty-five Allanthus glandulosa shoots, in the spring of 1930, were distributed as follows (see, Table 1 ). Fifty-six shoots developed one branch each, ninety-four developed two branches each, fifty-five developed three branches each, fifteen developed four branches each, two developed five branches each, two others developed six branches each, and one developed elght branches.

The branches established by the random sample of four hundred thirty-six shoots, in the spring of 1931, were distributed as foliows ( shoots developed a solitary branch each, one hundred sixtyfour developed two branches each, one hundred twenty-f1ve developed three branches each, thirty-four developed four branches each, elght developed five branches each, and one shoot grew six branches.

A comparison of the method of branching found in the two samples show a similarity in the number of branches developed by the shoots in the two seasons. The minimum number of branches established by a parent shoot in both samples was one, and the maximum number was elght. The difference in the maximum number of branches for a shoot in the two seasons was due to a single case. One shoot in the first sample had eight branches, while the largest number of branches on a 
Table 1 shows the correlation in the number of branches developed on parent shoots 71 th the position of uppermost branch development on those shoote. (1930)

\begin{tabular}{|c|c|c|c|c|c|c|c|c|c|}
\hline & 1 & 2 & 3 & 4 & 5 & 6 & 7 & 8 & Total \\
\hline 17 & & $\$$ & 3 & & & & & & 7 \\
\hline 16 & & 1 & 2 & & & & & & 3 \\
\hline 15 & 4 & 1 & 5 & 1 & & & & & 11 \\
\hline 14 & 1 & 4 & 2 & 1 & & & & & 8 \\
\hline 13 & 4 & 10 & 4 & 2 & & & & & 20 \\
\hline 12 & 6 & 11 & 4 & & 1 & & & & 22 \\
\hline 11 & 3 & 9 & 3 & & & & & & 15 \\
\hline 10 & .5 & 8 & 7 & 1 & & & & & 21 \\
\hline 9 & 10 & 6 & 1 & & & & & & 17 \\
\hline 8 & 3 & 10 & 1 & 1 & 1 & & & & 16 \\
\hline 7 & 6 & 9 & 4 & 2 & & & & & 21 \\
\hline & 6 & 10 & 6 & 1 & & 1 & & 1 & 25 \\
\hline 5 & 3 & 5 & 6 & & & & & & 14 \\
\hline 4 & 1 & 2 & 2 & 1 & & 1 & & & 7 \\
\hline 3 & 1 & 2 & 2 & 2 & & & & & 7 \\
\hline 2 & & 2 & 3 & 3 & & & & & 8 \\
\hline 1 & 3 & & & & & & & & 3 \\
\hline Total & 56 & 94 & 55 & 15 & 2 & 2 & 0 & 1 & 225 \\
\hline
\end{tabular}

Average number of branches for each shoot $=2.22 \pm .19$

Average bud position from which uppermost branch developed on parent shoot $=9.15 \pm .68$ Coefficient of correlation 
Table 2

Table 2 shows the correlation in the number of branches developed on parent shoots to the position of uppermost branch development on those shoots. (1931)

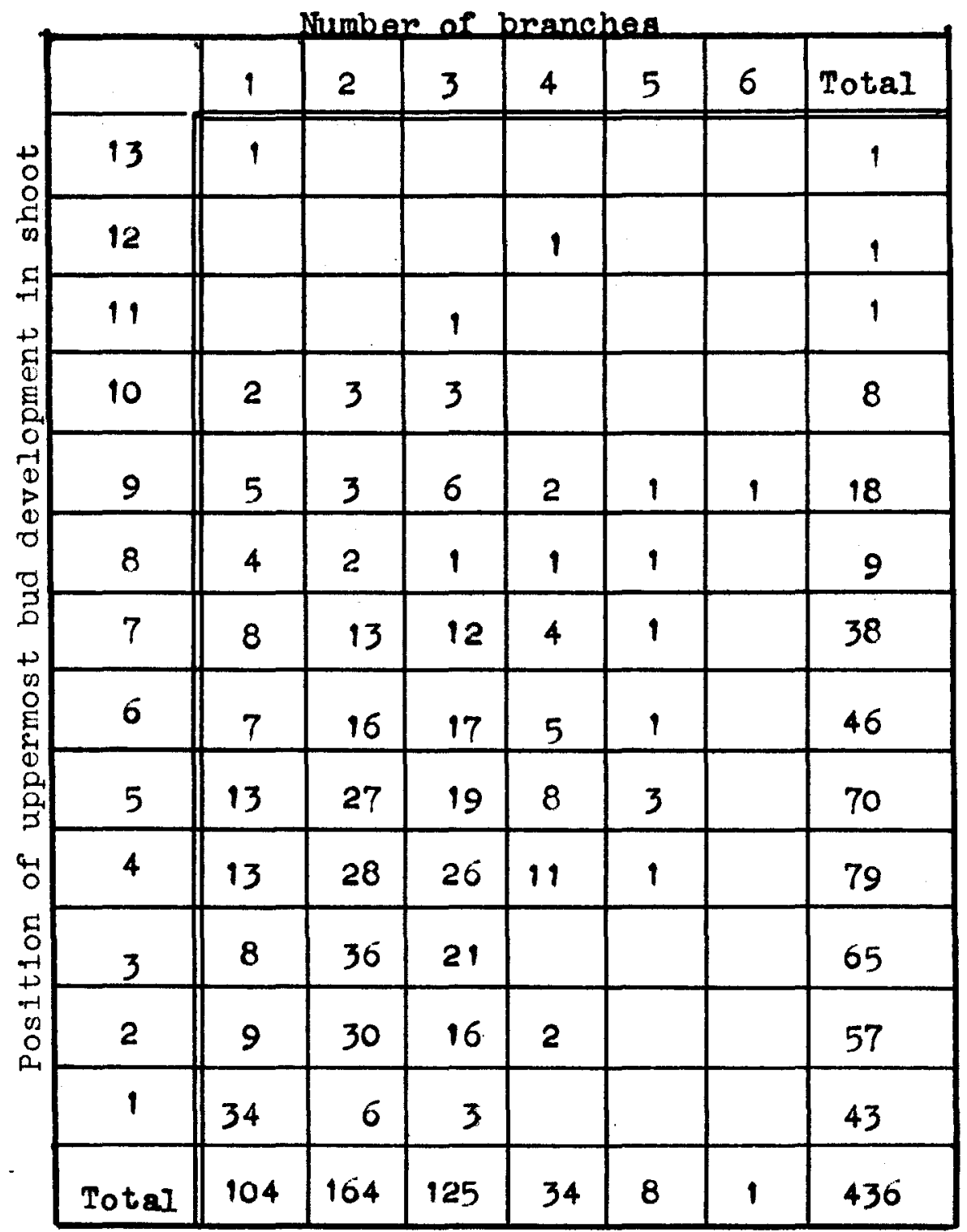

Average number of branches for each shoot $=2.27 \pm .141$

Average position of uppermost branch development on parent shoot $=4 \cdot 38 \pm .112$

Coefficient of correlation 
shoot in the second sample was six. The average number of branches for a shoot in the 1930 sample was 2.22 and the average number in the 1931 sample was 2.27. The mode in both samples was two. It is evident from these data that while the number of branches established by a shoot may vary from one to at least elght, the average shoot has a tendency to establish two branches.

THE POSITION OF BUDS THAT DEVELOPED INTO BRANCHES

Two factors were observed in the position of buds which were developed into branches on the parent shoots. First, the bud position from which the uppermost branch was established upon the shoot. Second, the bud positions from which lower branches were established upon the shoot.

In the $1930 \mathrm{sample}$, three shoots of the two hundred twentyfive established their uppermost branches from their tip buds. The remaining two hundred twenty-two established their uppermost branches from lower buds. The lowest position from which an uppermost branch was established was the seventeenth bud. The average position of uppermost branch growth in the sample was the 9.15 bud ( gee, Table 1, page 14 ).

In the 1931 sample, uppermost branches were established upon parent shoots from the first to the thirteenth bud position. The average position was the 4.38 bud. It is evident that the averace position of uppermost branch development was 4.77 buds less than in the 1930 sample ( see, Table 2, page 15 ). 
These data indicate that while the uppermost branch may be established through the development of any one of the firgt seventeen buds in the shoot the chances are greatest that the upermost branch on a shoot w111 be a development of a bud between the fourth and the ninth position.

The position of branches relative to each other, in the cases of multiple branch development, showed the following variation. In the $\$ 930$ sample, nineteen of the branching shoots did not have their branches in a regular descending order. The branches were separated by one or more buds which falled to establish branch growth ( see, Plate I-A). In the 1931 sample, elghty-one shoots exhibited a similar nonsystemic order in branch arrangement. In the remaining cases of multiple branching in both samples the branches were arranged in a basipetal order (see, Plate I-B). As the non-sjstemic arrangement equaled but eleven per cent of the total multiple branching in the first sample and twenty-four per cent of the cases of multiple branching in the second sample, it is evident that the normal tendency in branching was systemic.

A comparison of the shoots that established branches from their tip buds with the shoots that falled to establish such branches shows that non-systemic arrangement of branches is a character accompanying the fallure of the shoot in establishIng a branch from its tip bud. The three shoots that established branches from their tip buds, in the 1930 sample, developed no other branches ( see, Table 1, page 14 ). 


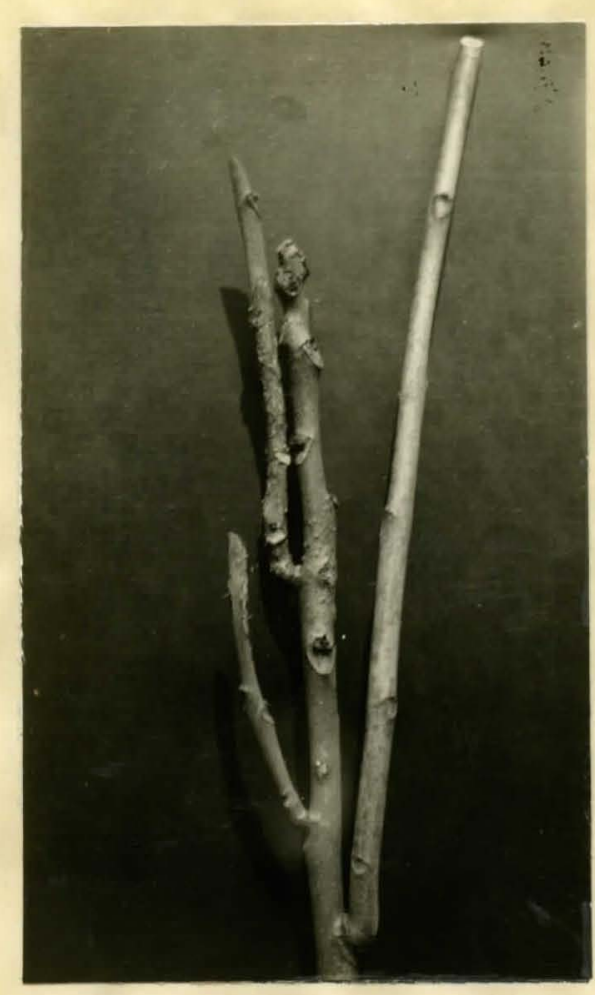

A

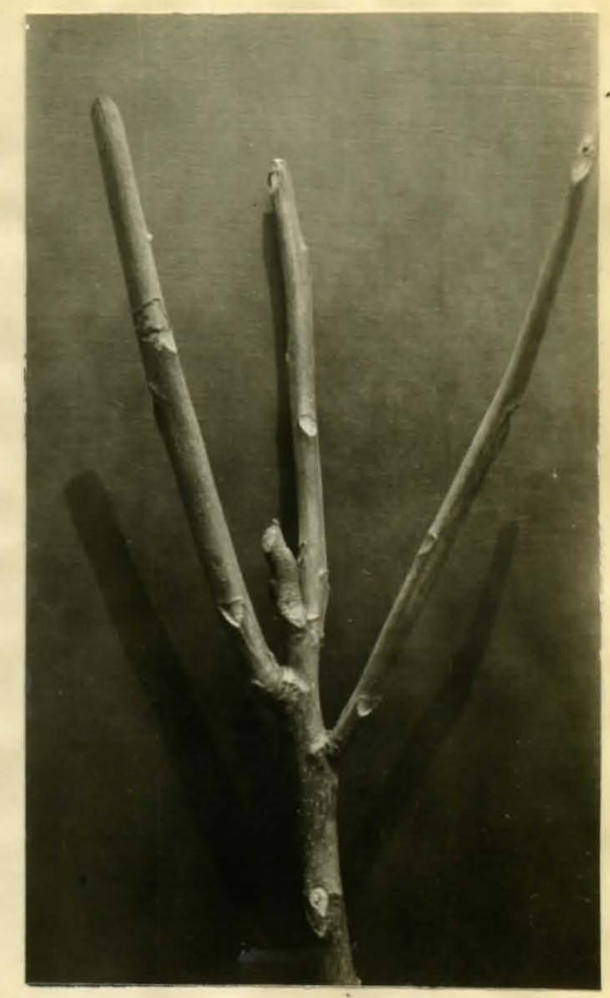

B

Plate I

A Shows a non-gystemic arrangement of branches on a parent shoot. Non-systemic arrangement occurred 19 times in the 169 cases of multiple branching in the 1930 sample and 81 times in the 332 cases of multiple branching in the 1931 sample.

B

Shows a systemic arrangement of branches found on parent shoots. Systemlc arrangement was found 142 times in the 161 instances of multiple branching in the 1930 sample and 251 times in the 332 instances of multiple branching in the 1931 growth. 
In the 1931 sample there were forty-three shoots that estabIlshed branches from their tip buds ( see, Table 2, page 15 ). Thirtj-iour of these shoots established no other branches, six developed an additional branch each from their second buds, and three developed two adutional branches each from their second and third buds ( of branches developed by the forty-Bix parent shoots, in the combined samples, which established branches from their tip buds was 1.3 . The average number of branches developed by the two hundred twenty-five shoots in the 1930 sample was 2.22 and the average number of branches developed by the four hundred thirty-8ix shoots in the 1939 sample was 2.27 . A combined average of 2.25 branches for each shoot in the two samples. That this additional branch for each shoot in the average of the tro samples was due to fallure of the tip bud and not to a progressive degree of apical bud fallure is shown by the fact that there was no regularity in correlating the degree of apical bud fallure, below the first bud, with the numiver of branches established. The average number of branches developed on those shoots whose uppermost branch was a development of the second bud on the shoot was 2.3 branches for each shoot. The average number of branches developed by those shoots whose uppermost branch was a development of the seventeenth bud was 2.4 branches for each shoot. The average number of branches developed by those shoots whose uppermost branch was a development of bud positions between the second and the seventeenth varied between 1.9 and 3.0 branches for 


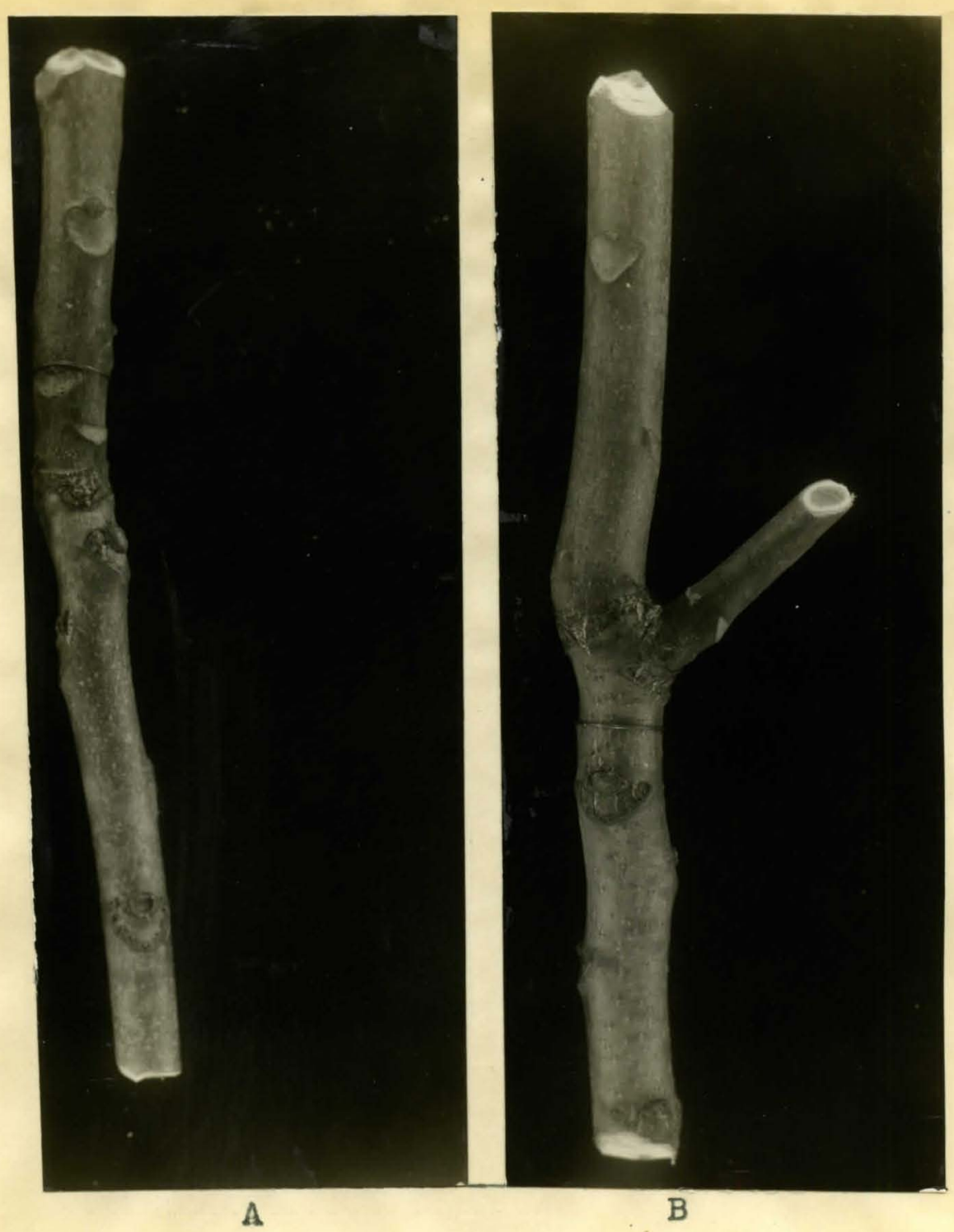

Plate II

A. The type of branch growth resulting when the apical bud alone developed. This pattern occurred in each of the three instances of Apical bud development in the 1930 sample. It was found 34 times in the $43.1 \mathrm{nstances}$ of aplcal bud development on the 1939 growth.

B. The type of branching found $\mathrm{six}$ times in the 43 cases of apical bud development of 1931. 
each shoot ( see, Fig. 1 ).

Arrangement of branches in a non-systemic order was found only upon the shoots that falled to establlsh branches from their tip buds. In the nine shoots that established branches from their tip buds and also developed branches from lower buds, the branches were in a regular descending order ( see, Plate II ). The shoots that did not establish branches from their tip buds frequently developed their branches in a non-systemic order ( see, Plates I-A, II, and III $).$ 
Fig. 1

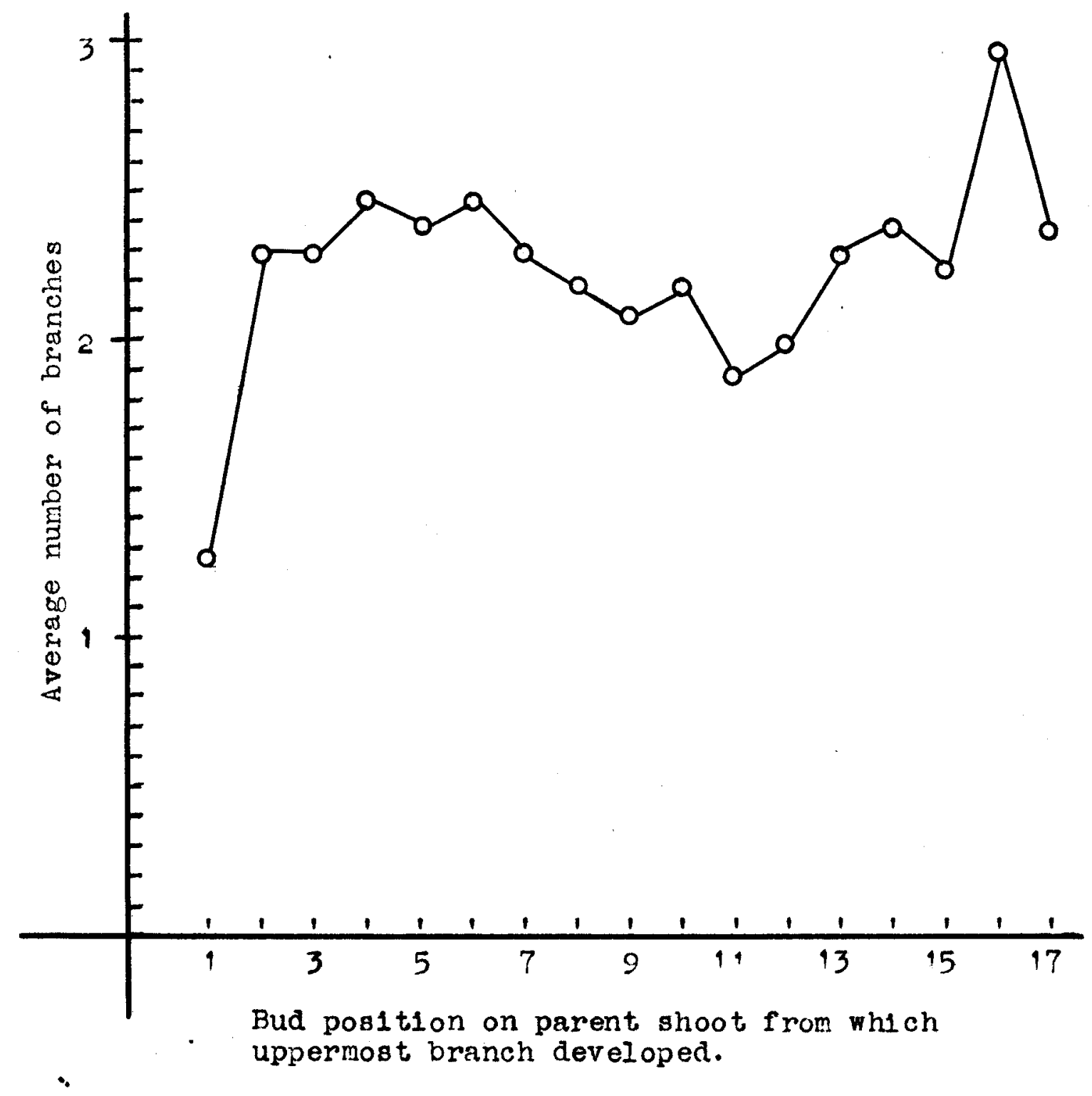

F1g. 1 shows the average number of branches developed by the shoots in the two samples correlated to the position of uppermost bud development ( 1930-1931). 


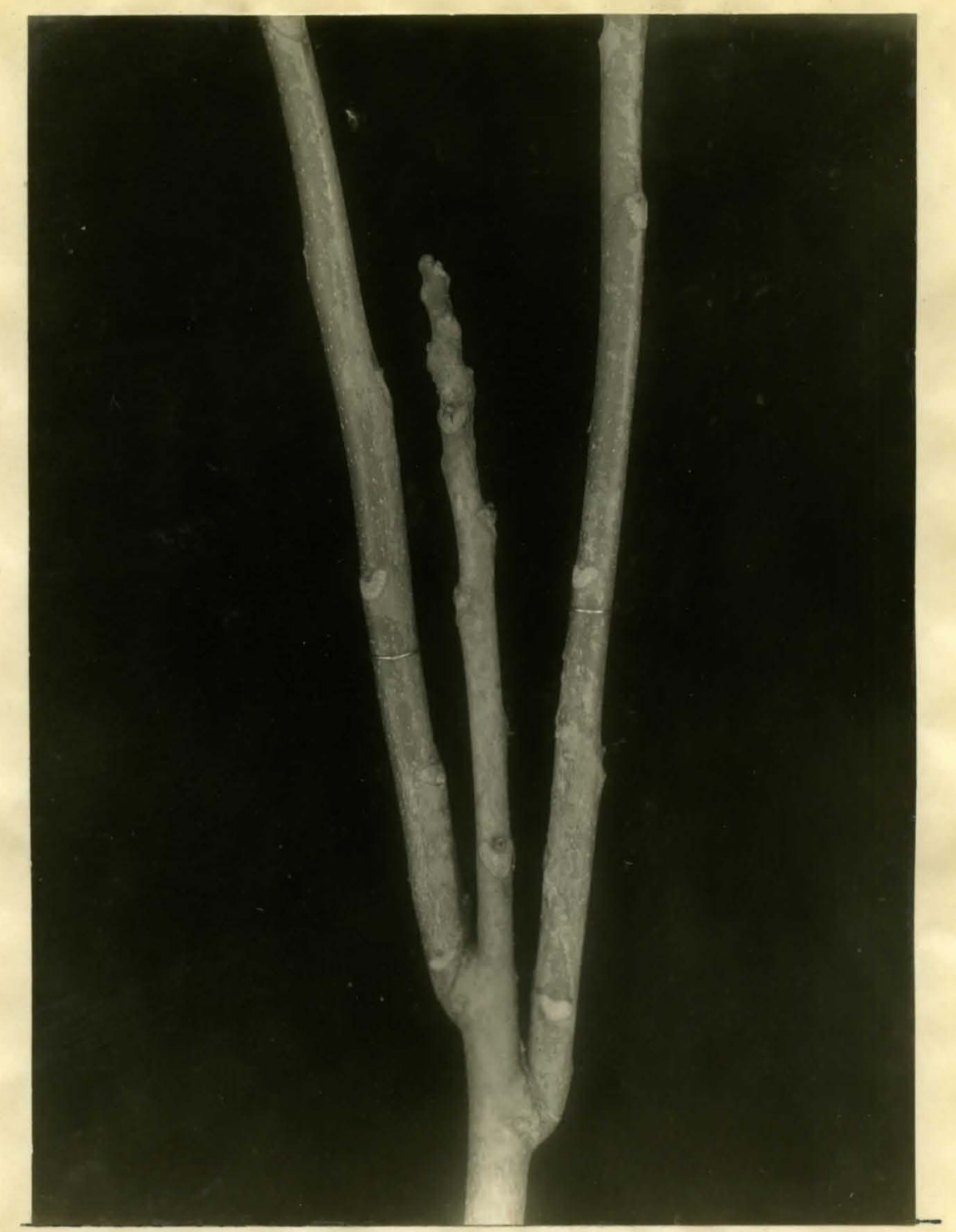

Plate III

Plate III shows the dieing back of that portion of the parent shoot that was distal to the uppermost grow1ng bud. Dead spurs like this were always found in both samples whenever the tip bud did not develop into a branch. The length of the spur depending upon the degree of bud fallure in the apex of the shoot. 


\section{SUMMARY}

The lack of terminal bud development in Al lanthus glandulosa determines 1 ts plan of branching. Extension-growth after dormancy was dependent entirely upon the development of one or more of $1 \mathrm{ts}$ axillary buds. The number and arrangement of branches established from these buds was determined by the bohavior of the tip bud in the shoot. When a branch was established from the tip bud other branching was usually absent; when other branches were developed they were In a regular deacending order upon the parent shoot ( Bee, Plate II ). When no branch was established from the tip bud, the average bud position from which an uppermost branch grew ranged from the fourth to the ninth bud. The number of branches varied between one and elght with an average of more than two ( $\mathrm{see}, 1$, page 22 ). Their arrangement was systemic or non-systemic ( 
THE RELATIONSHIP OF THOSE FACTORS IDENTIFIED FITH THE NATURE OF THE PLANT ( (1) MATURITY OF THE BUDS, (2) FOOD RESERVES IN THE ADJACENT SUPPORTING TISSUES, (3) WATER CONDUCTIVE ABILITY OF THE SUPPORTING TISSUES, AND (4) DORMANCY / TO THE GROTTH OF AXILIARY BUDS UPON SHOOTS OR TWIGS OF AIIANTHUS GLANDULOSA. 
THE MATURITY OF THE BUDS

The indefind te growth hablt, so unusual in trees, but shown by Blakeslee and Jarvis (3) to be characteristic of Allanthus glandulosa, may easily lead one to suppose that maturity of the apical buds is entirely dependent upon envi ronmental factors. While food supply, available moisture, and temperature changes do affect the development of buds upon the distal end of the growing shoots these factors are able to affect the apical buds only by accidental intensification. The performance of the buds upon cut shoots forced into growth shows that, it is characteristic of the shoots of Al Ianthus glandulosa to develop $1 \mathrm{ts}$ buds to the degree of maturity that they are carried through the quiescent period in spite of the indefinite growth habit. Normal bud growth upon 268 shoots out of a random sample of 281 developed leaves from their tip buds when forced into orowth by the moisturetemperature method ( see Table 3 ). The tip buds that failed to develop into leaves, excepting seven shoots that falled to grow, were much smaller than other buds on that region of the twies. Their supporting internodes were also less than four milimeters in length. This relationship of size to maturity of buds was found to exist only in the case of the very small tip buds. In Eeneral, the size of buds upon a shoot was proportinate to the diameter of the supporting structure. The relatively smaller buds upon shoots of lesser dianeter were able to unfold their leaves when forced into 
Table 3

Table 3 shows the position of developing buds in 281 cut shoots of Allanthus Elandulosa forced into Growth by the molsture temperature-method from the time of leaf fall untll growth was resumed in the following spring. ( 1931-1932)

\begin{tabular}{|c|c|c|c|c|c|}
\hline $\begin{array}{l}\text { Sample } \\
\text { taken }\end{array}$ & $\begin{array}{l}\text { No. of } \\
\text { twigs in } \\
\text { sample }\end{array}$ & $\begin{array}{l}\text { Frequency } \\
\text { of tip } \\
\text { bud growth }\end{array}$ & $\begin{array}{l}\text { Frequency } \\
\text { of no } \\
\text { devel op- } \\
\text { ment }\end{array}$ & $\begin{array}{l}\text { Frequency } \\
\text { of } \\
\text { gystemic } \\
\text { growth }\end{array}$ & $\begin{array}{l}\text { Frequency } \\
\text { of non- } \\
\text { syotemic } \\
\text { Erowth }\end{array}$ \\
\hline Nov. 2 & 16 & 11 & 5 & 6 & 5 \\
\hline Nov. 20 & 18 & 15 & $-\frac{1}{2}$ & 15 & $\frac{2}{1}$ \\
\hline Dec. 2 & 18 & 18 & 0 & 17 & 9 \\
\hline Dec. 20 & 18 & 18 & 0 & 18 & 0 \\
\hline Dec. 28 & 18 & 17 & 0 & 17 & 1 \\
\hline $\operatorname{Jan} \cdot 8$ & 16 & 16 & 0 & 16 & 0 \\
\hline Jan. 16 & 24 & 24 & 0 & 24 & 0 \\
\hline Jan. 31 & 36 & 36 & 0 & 36 & 0 \\
\hline Feb. 10 & 30 & 29 & 0 & 30 & 0 \\
\hline $\mathrm{Feb} .20$ & 19 & 17 & 0 & 19 & 0 \\
\hline Feb.25 & 15 & 15 & 0 & 14 & 1 \\
\hline Mar. I & No samp & e taken -- & uds rere b & eaking & e, Plate \\
\hline Mar. 5 & Sample & aken one ho & $r$ after $d r$ & In tempe & ature \\
\hline Mar. 7 & 31 & $\frac{25}{30}$ & 0 & 28 & 3 \\
\hline Total & 281 & 268 & 7 & 262 & 12 \\
\hline
\end{tabular}

The development recorded was found upon the shoots when they were gathered. Frost had killed these buds. Lower buds could not be induced to grow by the molsture-temperature method. 
growth as were those buds upon shoots of major diameter.

A comparison of the size of buds upon shoots with the time required for leaf development shows that the size of the bud, excepting the very small tip bud, is not the prime factor in shoot development. Table 3 shows that leaf growth was found in 268 tip buds. Lower ranking buds grew in regular order upon 262 of the shoots. W1 th but fer exceptions, the earliest and most rapid growth was observed in the tip bud and gradually declined in a proximal direction (see, Plate IV). The tip buds were not the largest buds on the shoots. A series of measurements made of the size of buds upon twentyfive shoots chosen at random shows the buds between the sixth and the ninth position from the tip of the shoot to have been the largest ( see, Fig. 2 ). The same measurements also show that the buds in a proximal direction from the ninth were larger than the corresponding buds in a distal direction. But as shown in Plate IV, the lower ranking buds were elther alower in developing their leaves or falled to begin growth al together. This fallure to develop ras not due to immatur1 ty because leaf development from lower ranking buds was obtained when the upper buds were removed from the shoots. Simlar positive resulta were obtained by clipping away the top of the shoot el ther before or after the forcing process was begun. The only difference observed in the development of leaves from Iower buds on the shoot, when the rivalry of upper buds was removed, was in the time required for leaf unfolding. A test of the time required for growth of leaves 


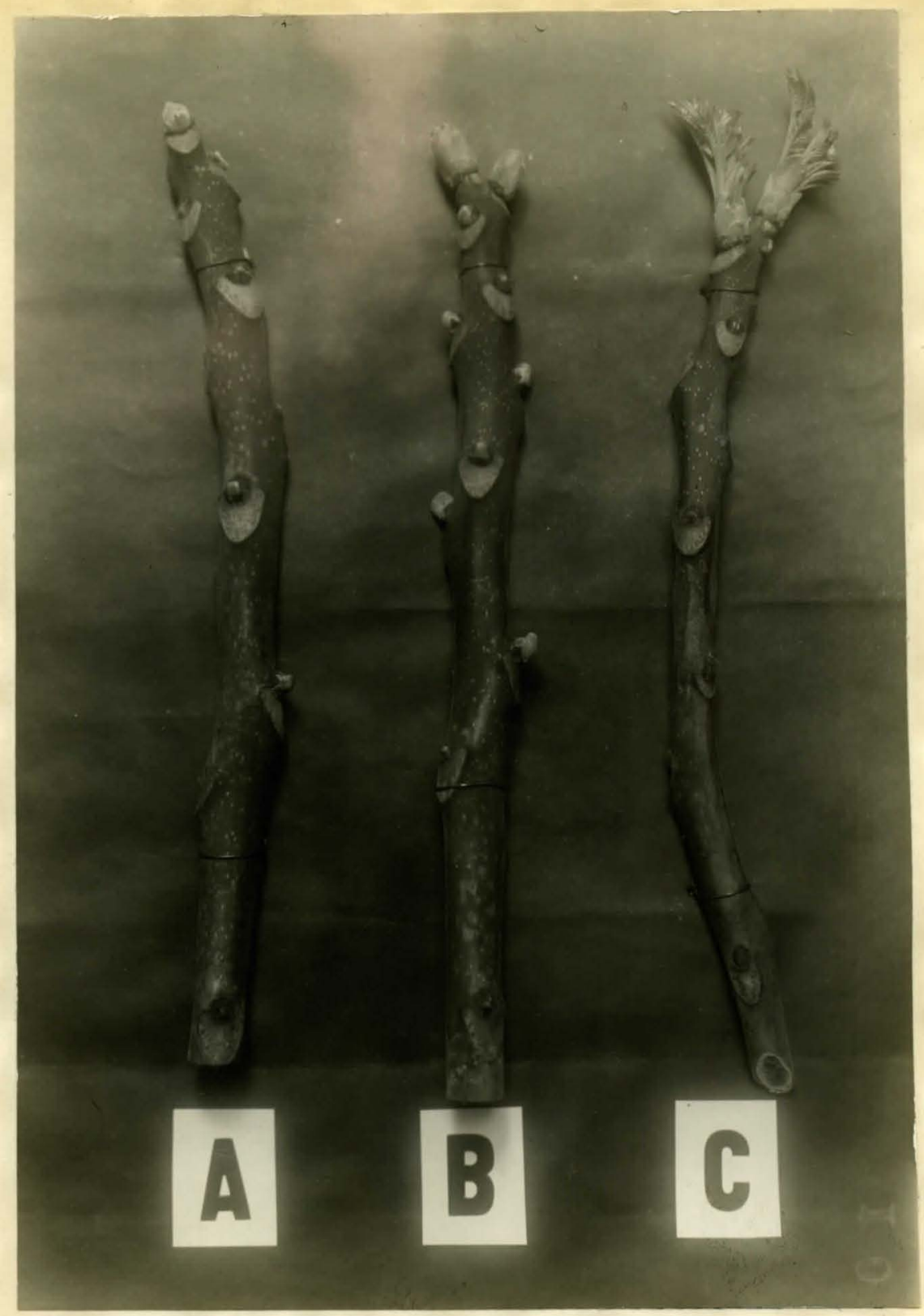

Plate IV

Plate IV illustrates the characteristic bud growth found in cuttings forced into growth by the molsturetemperature method. The shoots were gathered on February 25, 1932.

A. _ shows the minimum result of a five daj treatment.

B. _ shows a median result in the same number of days.

C. _- shows the maximum growth in five days. 
F1E. 2

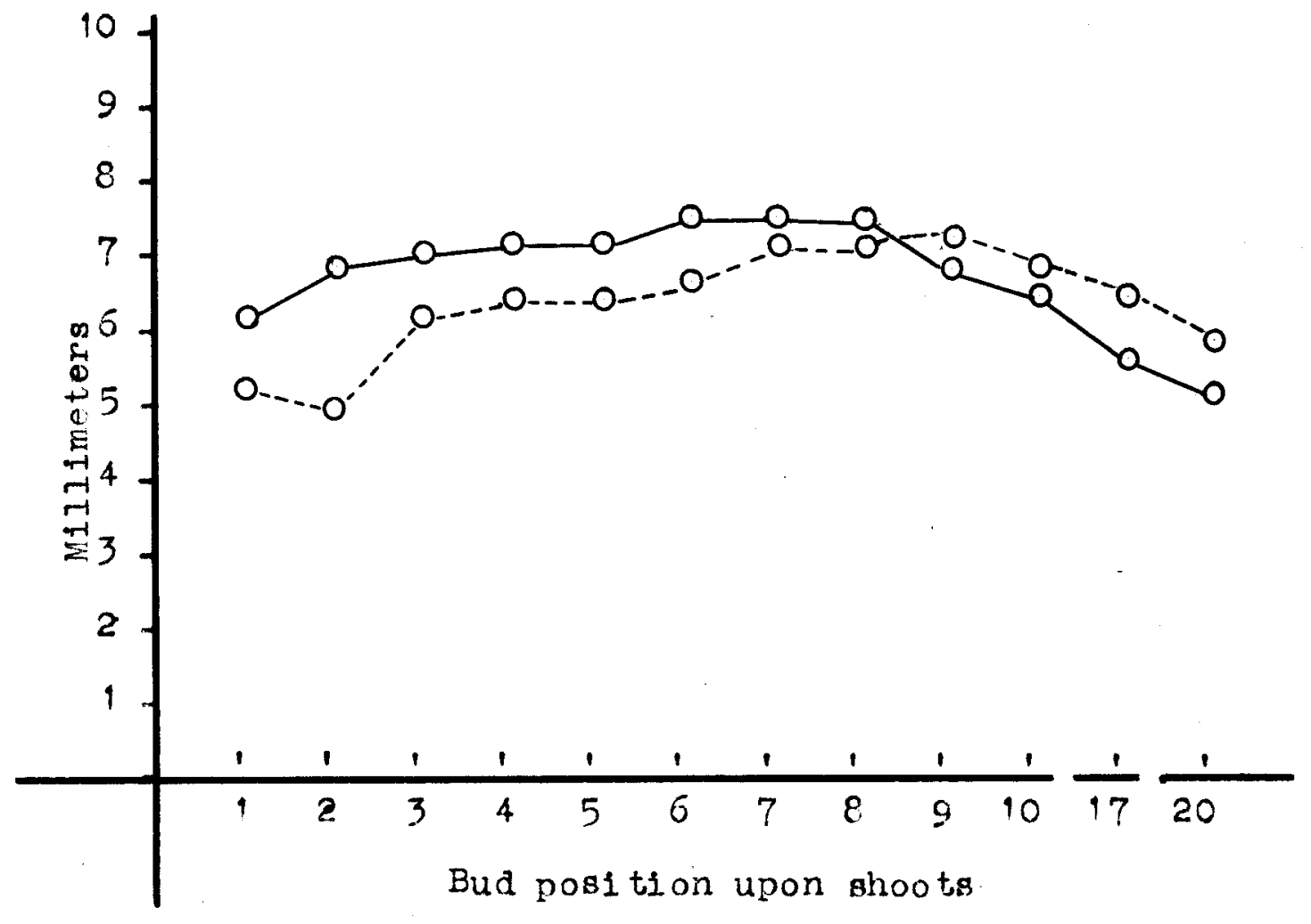

Fig. 2 show the average size of buds on twenty-five shoots chosen at rendom. average vertical distance through bud.

....- average horizontal distance through bud. 
from the various bud positions on lone shoots was made by selecting a random sample of twenty-five shoots and arranging them into six groups. Each of the four shoots in a group was sectioned so that the top bud of the first section was the tip bud upon the shoot. Each group in the three lower sections was cut so that buds ranging from the ninth to the

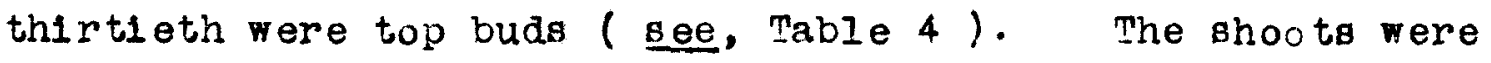
gathered on the thirty-first day of January and subjected to the molsture-temperature treatnent, for twelve days. At the close of this period the tip bud on the first section of each group was unfolding 1 ts leaves, and from two to seven lower buds were growing. The uppermost bud on the second section of each shoot was growine actively but was less advanced than the tip buds of the first section. Lower buds were likewise active. The uppermost bud on the third section of ench shoot was growine actively but developrent was less advanced than in the two upper sections of the shoots. Growth in lower buds was also observable. The uppermost bud on the fourth section of each shoot in five of the groups was growing but the degree of development was markedly less than that found in the three upper sections of the shoots. 2

- This ability of lower buds to grow was also observed in the shoot growth found in the thicket. The destruction by frost of apical buds of shoots in the spring of 9.32 regulted in the development of twies from every bud position on the shoot. In

The shoots were too short for a fourth section in group six. 
Table 4

\begin{tabular}{|c|c|c|c|}
\hline Group \# & Section & Top bud & Bud growth found after 12 days \\
\hline 1 & 1 & 1 & \multirow{6}{*}{ About to unfold 1 to leaves } \\
\hline 2 & 1 & 1 & \\
\hline 3 & 1 & 1 & \\
\hline 4 & 1 & 1 & \\
\hline 5 & 1 & $T$ & \\
\hline 6 & 1 & $I$ & \\
\hline 1 & 2 & 9 & \multirow{6}{*}{ Very active but less advanced } \\
\hline 2 & 2 & 10 & \\
\hline 3 & 2 & 11 & \\
\hline 4 & 2 & 12 & \\
\hline 5 & 2 & 13 & \\
\hline 6 & 2 & 10 & \\
\hline 1 & 3 & 17 & \multirow{6}{*}{ Very active but less advanced } \\
\hline 2 & 3 & 18 & \\
\hline 3 & 3 & 12 & \\
\hline 4 & 3 & 21 & \\
\hline 5 & 3 & 22 & \\
\hline 6 & 3 & 30 & \\
\hline 1 & 4 & 25 & \multirow{6}{*}{$\begin{array}{l}\text { Active but considerably } \\
\text { less advanced than the top } \\
\text { buds on the other sections }\end{array}$} \\
\hline 2 & 4 & 26 & \\
\hline 3 & 4 & 27 & \\
\hline 4 & 4 & 28 & \\
\hline 5 & 4 & 29 & \\
\hline 6 & $* /$ & & \\
\hline
\end{tabular}

Table 4 shows the bud development found on shoots cut into four sections each, after 12 days of molsture-temperature treatment. 24 shoots wore gathered on January $31,1932$.

The shoots were divided into $81 x$ groups and sectioned so that the uppermost buds upon the sections ranged from the first to the thirtieth bud. The results show that the buds are matured.

The shoots were not lone enough to provide a fourth section in the sixth group. 
some cases buds on the previous jear's wood were growing ( gee, Plate V).

It is, therefore, evident from these data that all buds of Ailanthus glanduloga, with exception of the occasional tiny tip buds, are mature. The fallure of some buds to develop Into shoots, after the dormant season, must be due to factors other than lack of maturity. 


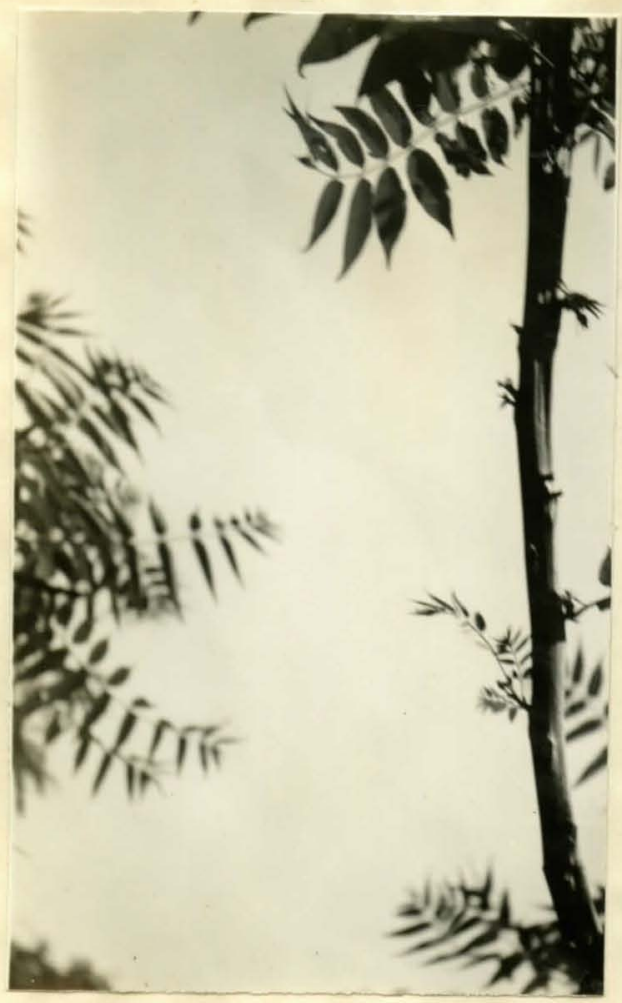

A

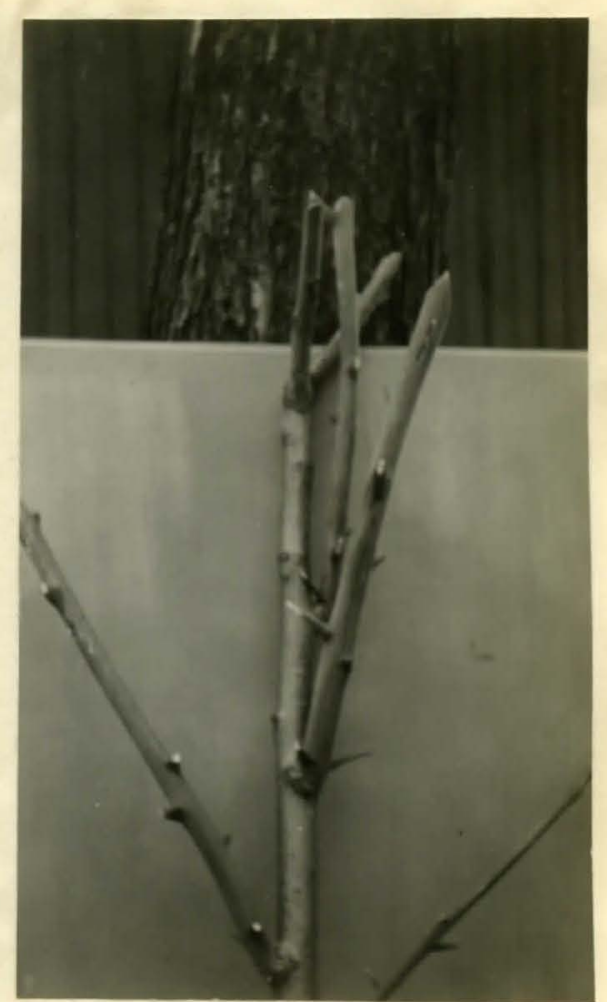

B

Plate V

Plate $V$ shows basal bud development upon shoots whose tips were injured by the low temperature which prevailed from the fifth to the fifteenth day of March 1932.

A. - shows lower buds upon the old wood in unsuccessful rivalry with low basal buds beneath the frost killed area of the new wood.

B. shows successful twig development found upon old wood beneath an entirely frost killed shoot. 


\section{FOOD RESERVES}

The experiment with cut shoots of Allanthus glandulesa to determine the maturity of their buds has shown that the stored food reserves in the cuttings are adequate to support the initial grow th of buds ( see, Plate IV). Inasmuch as all of the buds upon the cuttings did not grow when subjected to the forcing treatment it was considered possible that the necessary stored nutrient substances had been translocated to the growth region in the apex of the shoot. This upward translocation robbed the lower buds on the shoot of the necessary stored food with which to begin growth. Gardner (14) attributed a similar bud performance upon twigs of the Bartlett pear to a translocation upwards of nitrogen in the lower supporting tissues. Butler, Smlth, and Curry (4) also attributed the aplcal bud growth of apple twigs to an upward translocation of nitrogen to the growing point. A test of the distribution of stored food, in the tissues of A1 lanthus glandulosa, necessary to support initial bud Growth was made by subjecting very short sections of shoots to the moisture temperature treatment. Tips of shoots having but three buds grew as readily as longer shoots ( Plate VI ). Likewise, Iorer sections of shoots containing one bud were induced to grow by the same method. It was al so found that lower buds that had remained quiescent on forced shoots grem when the rivalry of upper buds was removed by clipping away the top of the shoot. 


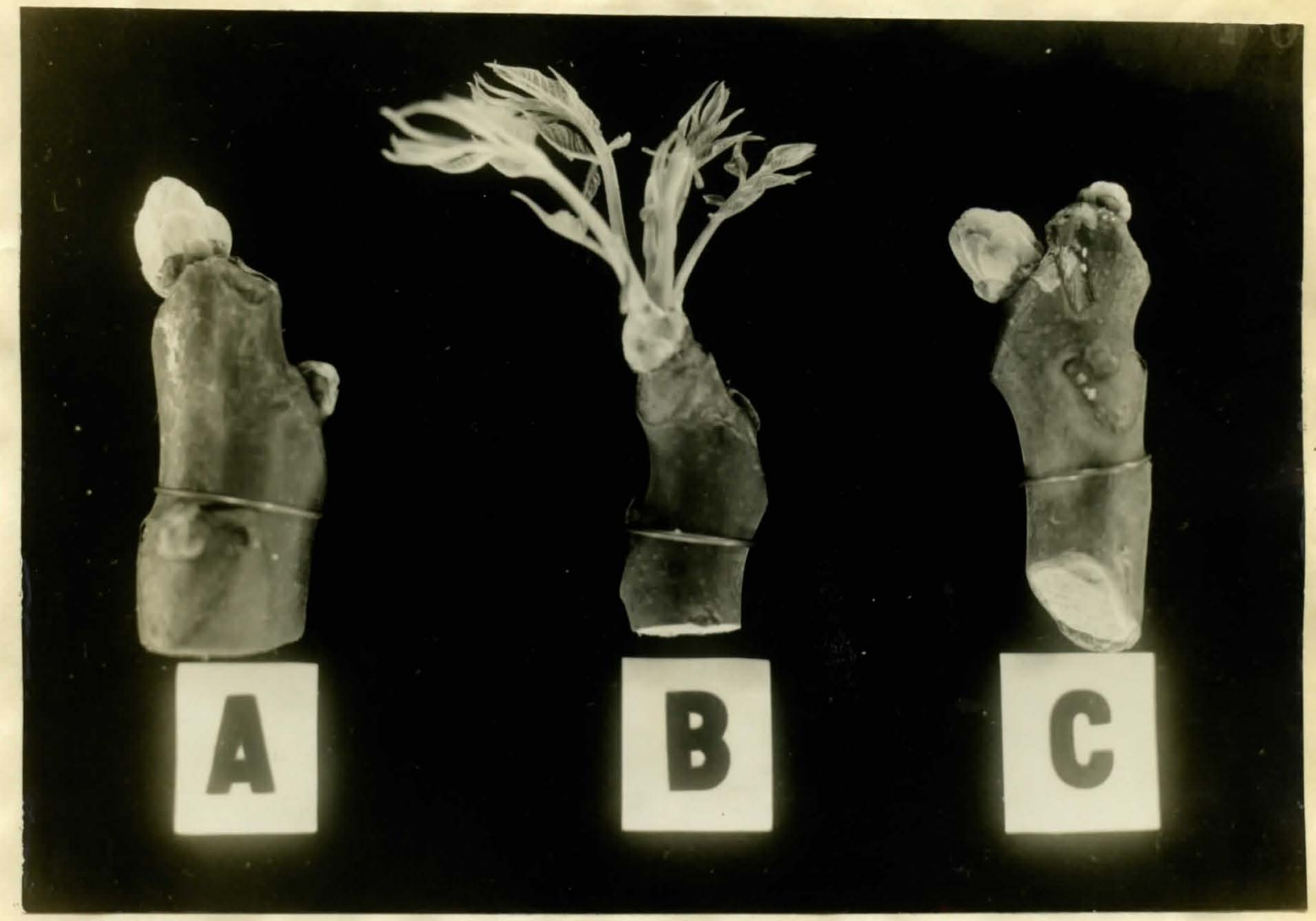

Plate VI

Plate VI shows the development of buds upon short lengths of parent shoots. The shoots were subjected to the molsture-temperature treatment for the aame number of days. 
The bud performance upon these short sections of shoots indicates that the avallable stored food in the bud and 1 to intervening internode is ample to support inl tial growth. Whether or not there was a translocation of nitrogen or some other substance from lower reglons of the internode was not determinable by this experiment. But the results do show that the initial growth from buds is not dependent upon food stored in the lower reglons of the shoot ( Bee, Plate VI). It 18, therefore, evident that the position of the branches found upon the shoots in the 1930 and 1931 samples of branching was not due to distribution or translocation of avaliable stored food materials in the shoots. The fact that lower buds had the necessary available food material to support inftial growth but did not grow until the rivalry of upper buds was removed show that stored food material is not the factor that determines the number of buds that begin shoot development. The results of bud forcing upon cut shoots show that all buds have the necessary avallable stored food material, e1ther within their own tis sues or in the immediately adjacent supporting tissue, to support inftial growth but only the apical buds begin growth under normal conditions. 


\section{CONDUCTION OF MOISTURE}

Conduction of molsture in the shoots of Allanthue glandulosa is the function of the latest formed wood tissue. Red ink in the water oupply of the cutting caused a falrly. uniform deposit of pigment in the intercellular spaces of this tissue. Removal of the bark and the pith of the immersed part of the cutting did not affect the rise of moisture nor the behavior of 1 ts buds. It was found that the red staln was approximately proportional to the size of the shoot. It extended upward to the tip of the shoot but no descending path was perceptible. Shoots that had been subjected to the stain for several days bled more profusely when notched near the apex than when notched near the base.

While conduction was not uniform even in shoots of the same size, it was found that the average shoot brought directly from the thicket conducted molsture at the rate of approximately one half of an inch an hour. The rise of the stain was noticeably more rapid in the aplcal region of the shoots. Farmer (12) agsociated high conductive ability of the wood in the apical region of the sycamore with 1 ts characteristic, strone, teminal growth habit. The cuttings of Allanthus glandulosa show a natural tendency toward vigorous apical Erowth ( found upon the trees in two successive seasons show a characteristic failure of shoot development from tip buds ( see, Tables 1 and 2, pages 14 and 15). Farmer (12) found a 
similar dying back in the apices of young ash twigs and associated this bud fallure with the low water-conductive ability of 1 ts sapwood. As the ink stains in the sapwood of Allanthug shoots showed rapid conduction, and as they likewise indicated the upward path of water to be as near the basal as the apical buds, it is evident that water-conductive ability of Allanthus glandulosa buds is not a principal factor in affecting the growth of 1 ts buds. 


\section{DORMANCY}

The existence of an annual quiescent perlod for many of the roody perennials has been demonstrated by experiment. Covilie (6) studying the influence of cold upon the subsequent growth of Vaccinium corymbosum and other plants, concluded that, trees and shrubs of cold climates become dormant at the close of the growing season without the necessity of exposure to cold, and that the resumption of growth was instigated by agents that ended dormancy. While dormancy in many trees and shrubs has been demonstrated, extant literature does not include such a study made of Allanthus slandulosa. It is, therefore, still to be proven that this species of tree has a restine period.

The forcing of bud growth in molsture-temperature treated cuttings, brought to the laboratory from the period beginning with leaf fall in November until resumption of leaf growth in the following March, Indicates that Allanthus glanduloga is dormant for a short period ( see, Table 5 ). The first shoots gathered in November and subjected to the treatment gave no indication of growth for several weeks. After forty-one days of moisture-temperature treatment some of the tip buds developed to the point of leaf unfolding. Five of the shoots brought to the laboratory on the ninth day of November and three gathered on the twentieth day of the same month could not be forced by this treatment. The eighteen shoots gathered on the second day of December unfolded leaves 
Table 5

Table 5 ahows the minimum and the maximum number of days required for the development of one or more buds, in the 281 forced shoots, to the staise of growth shown in Plate VI-A.

\begin{tabular}{|c|c|c|c|}
\hline $\begin{array}{l}\text { Treatment } \\
\text { begun }\end{array}$ & $\begin{array}{l}\text { Number of } \\
\text { twigs used }\end{array}$ & $\begin{array}{l}\text { Number of days } \\
\text { bud development } \\
\text { Minimum }\end{array}$ & $\begin{array}{l}\text { quired for apical } \\
\text { Maximum }\end{array}$ \\
\hline Nov. 9 & 16 & 41 & $\begin{array}{c}5 \text { failed to } \\
\text { develop }\end{array}$ \\
\hline Nov. 20 & 18 & 33 & $\begin{array}{c}3 \text { failed to } \\
\text { develop }\end{array}$ \\
\hline Dec. 2 & 18 & 31 & 33 \\
\hline Dec. 20 & 18 & 26 & 30 \\
\hline Dec. 28 & 18 & 22 & 27 \\
\hline Jan. 8 & 16 & 20 & 29 \\
\hline Jan. 16 & 24 & 19 & 23 \\
\hline Jan. 31 & 36 & 15 & 17 \\
\hline Feb. 10 & 30 & 10 & 12. \\
\hline Feb. 20 & 12 & 5 & 7 \\
\hline Fob. 25 & 15 & 3 & 6 \\
\hline Mar. 1 & $2 * /$ & . & \\
\hline
\end{tabular}

The tip buds on the shoots in the thicket were developed to the stage shown in Plate VII. 
from one or more aplcal buds in thirty-one to thirty-three days. The eighteen shoots gathered on the twentieth day of December began to unfold their first leaves in twenty81x to thirty days. Elghteen shoots gathered on the twenty-eighth day of December began to unfold their first leaves in twenty-two to twenty-seven days. The sixteen shoots gathered on the elght day of January unfolded their first leaves in twenty to twenty-one days. Twenty-four shoots gathered on the sixteenth day of January unfolded their first leavesanineteen to twenty-three days. Thirtysix shoots gathered on the thirty-first day of January unfolded their first leaves in fifteen to seventeen days. Thirty shoots gathered on the tenth day of February unfolded their first leaves in ten to twelve days. Nineteen shoots gathered on the twentieth day of February unfolded their first leaves in five to seven days. Fifteen shoots gathered on the twenty-fifth day of February unfolded their first leaves in three to six days. No shoots were gathered on the first day of March because bud growth in the thicket was actively established ( see, Plate VII).

These results indicate that Allanthus glandulosa is in a resting state for some time after leaf fall but is easily aroused by changing temperature, and posibibly by moisture supplj.

The position of bud development upon the shoots was, as previously shown in connection with the study of bud maturity, 


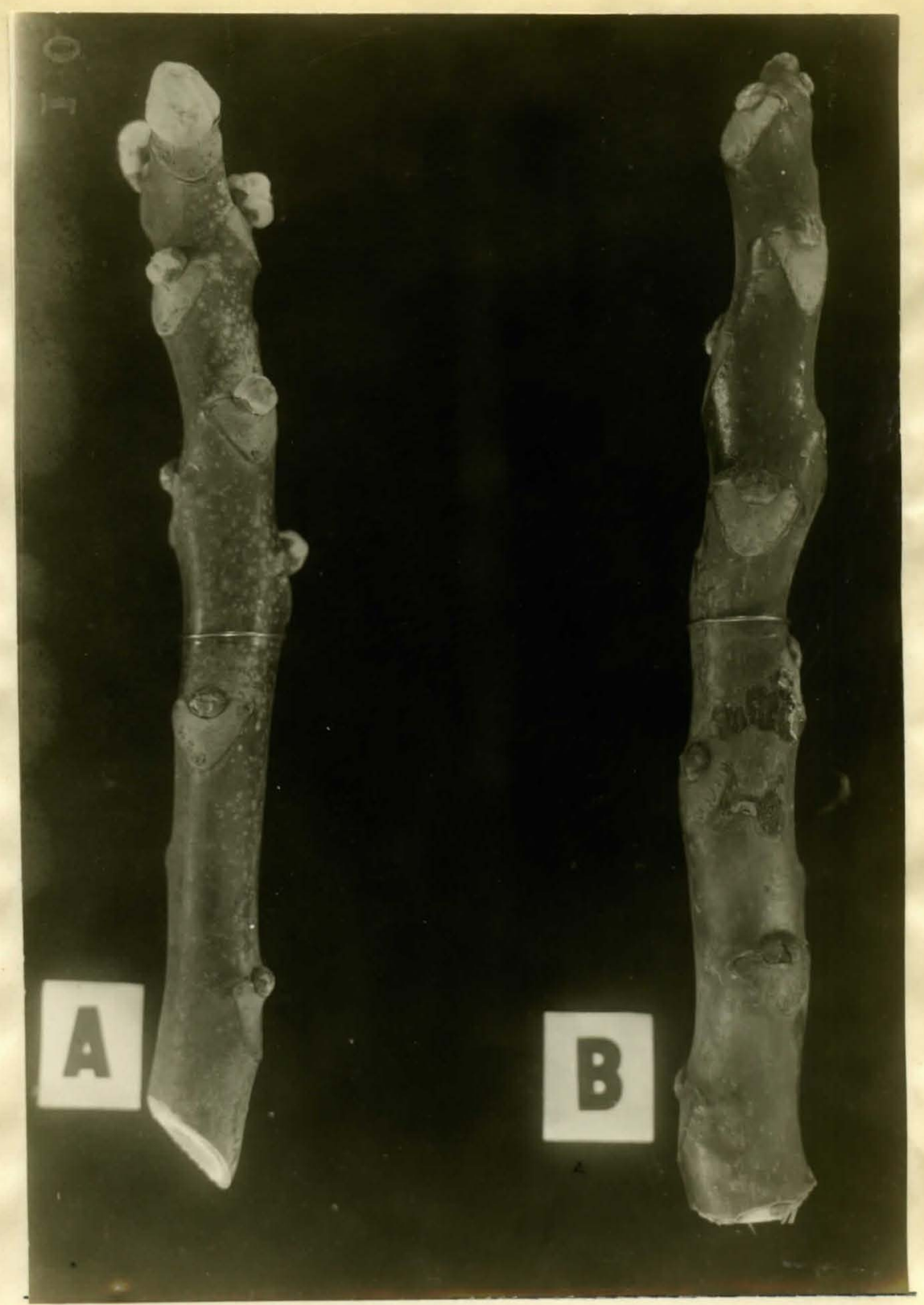

Plate VII

Plate VII shows the bud development found in the thicket on the first day of March 1932.

A. shows a near maximum development of buds.

B. shows a near minimum development of buds. 
characteristically apical ( see, Plate VIII). Likewlse, the position of growing buds on shoots in the thicket on the first day of Varch was also characteristically apical ( Plate VII ). Therefore, dormancy in Atlanthug glandulosa is evidently linked with a dominance of the uppermost bud. This dominance was characteristic but not absolute. The bud development on 268 cut shoots showed twelve instances of non-systemic development ( see, Table 3, page 27).

Dormancy in Allanthus glandulosa is evidently due, as Denny and stanton (10) found in Syringa vulgaris, to a condition within the bud itself. Domination of an accidental upper bud in place of the tip bud shows that dominance. In buds is determined by position in Ailanthus glandulosa and is not confined to the morphological tip bud ( see, Table 4, page $32)$. 


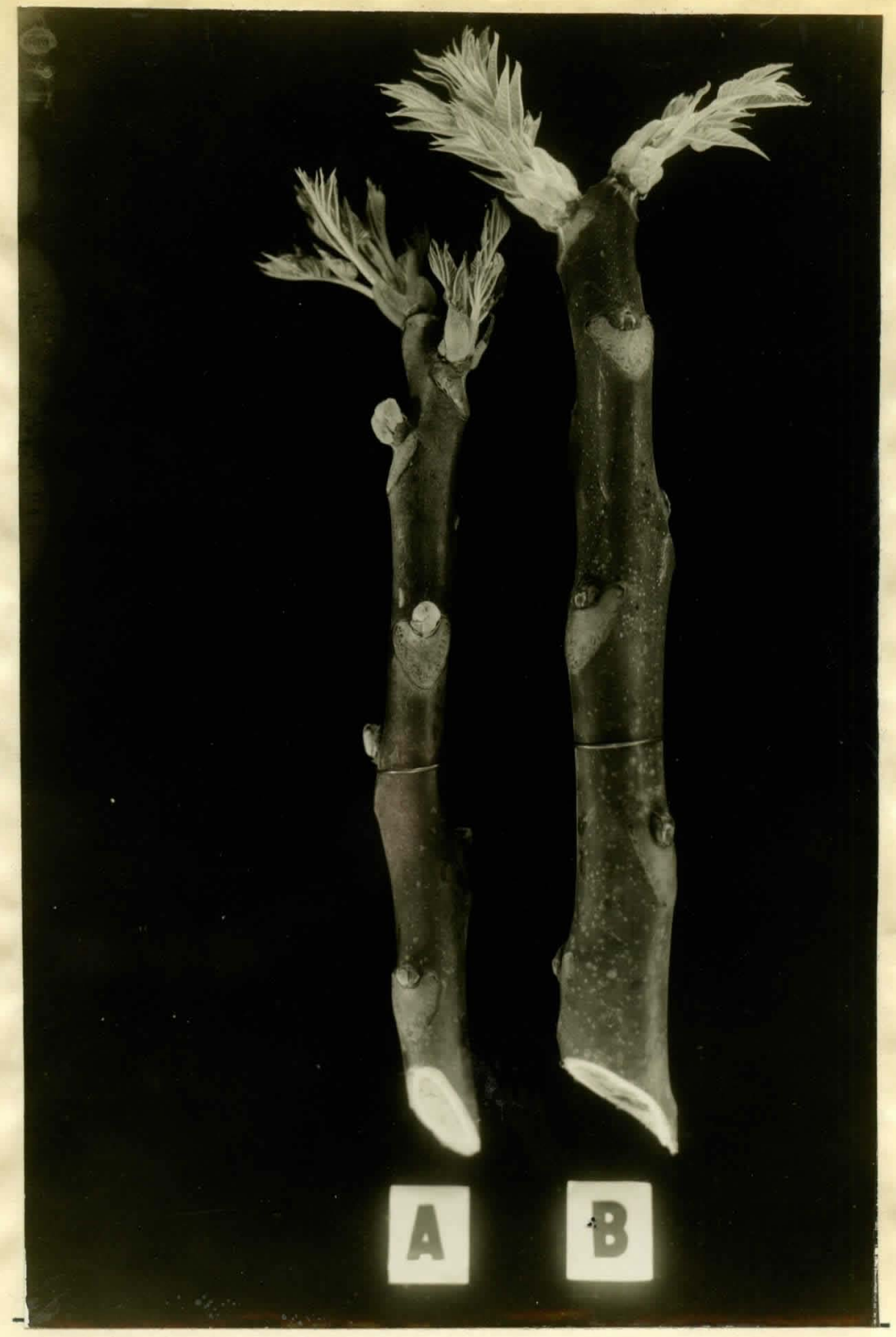

Plate VIII

Plate VIII shows the results of twenty-seven days of Holature-temperature treatment of shoots gathered on the twenty-elghth day of December 1931

A. shows the behavior of lower buds upon the larger part of the sample. the

B. shows the behavior of buds upon a small part of sample. 
MOISTURE, WOUND REACTION, AND TEMPERATURE IN THEIR RELATION TO THE BRANCHING IN AILANTHUS GIANDULOSA 


\section{MOISTURE}

When cut shoots were rept at room temperature but not subjected to moisture treatment no buds developed. Even six foot shoots whose cut ends were sealed with sureical tape to prevent evaporation were unable to produce visible growth in any of their buds. This bud failure could not have been due to immaturity as the shoots were a part of a random sample selected for the various tests.

It is evident from this lack of bud growth upon cutting kept at room temperature but not treated with water that the shoot does not contain the quantity of water necessary for leaf development. Bud development in Ailanthus is evidently conditioned by the rise of soll water in the plant. But as shown in the molsture-temperature treated cuttings ( see, Plate VII ) water conductivity of the sapwood was high. Bud growth was apical in both the cuttings in the laboratory and in the shoots found growing in the thicket on the first day of March 1932. As the bud failure found in both the 1930 and the 1931 samples of branching was distinctly apical, it is evident that lack of molsture id not cause this faliure or all of the buds upon the shoots would have falled. 


\section{WOUND REACTION}

Mutilations, such as the removal of the pith or the cutting away of the bark from the upper portion of the shoot, did not affect the growth behavior of buds upon shoots so mutilated. However, when the leaf scars were removed with the bark of the apical region, the buds in the mutilated area did not develop. Instead the buds immediately below the mutilated area began vigorous growth. The vigor of growth in the buda declined gradually in a proximal direction.

It was shown in the study of bud maturity that the cutting away of the upper portion of a shoot resulted in the development of one or more buds immediately below the injury ( see, Table 4, page 32 ).

Rubbing or lightly bruising of tissue adjacent to buds, which Covilie (6) found effective in producine bud growth in Vaccintum corymbosum, did not effect growth in buds of Allanthus glandulosa shoots. The upper buds still developed while lower buds, whose adjacent tissue had been lightly bruised, remained quiescent.

Severe bruising of the tis sue adjacent to low basal buds caused the following change in bud development upon the shoots. When a severe brulse was made above a basal bud the bud began to grow in unison with the apical buds. When severe bruises encircled the shoot more buds above and below the bruised area were aroused but the apical buds continued development. 
Bending of shoots did not cause a change in the growth behavior of their buds. Very little brulsing can be caused by bending of Ailanthue shoots because they are brittle and break easily. The bud fallure found in the 1930 and the 1931 samples of branching was not the result of broken shoots ( see, Plates I and III).

The bud performance upon mutilated, moisture-temperature treated shoots indicates that some of the non-systemic branch development found in the two samples may have been due to accidental bruises. Such bruises severe enough to cause stimulation might occur from the rubbine or striking together of branches, or buds might be destroyed by the same action. It is scarcely possible that even severe bruises could cause the dying back of shoots so erequently found in the two test samples of branching. 


\section{TEMP ERATURE}

The effect of low temperature, during the quiescent perlod, upon the subsequent growth of Allanthus glandulosa buds agrees with the conclusion of Coville (6), that uniformy Iow temperature during the resting stage of roody perennials 18 an adjunct to renewed growth of their buds in the spring. When freshly cut shoots, gathered in early January, were frozen in a refrigerator for twenty-four hourg and then submitted to the moisture-temperature treatment, bud development was accelerated and vigorous. The apical buds were dominant and no abnomal effect of the frost could be observed. This relation of low temperature during the winter to bud performance is shown also in the resulta obtained by forcing cuttings into growth from the time of leaf fall in November until the time of normal resumption of bud growth in the following spring. As previously shown in the study of bud dormancy ( see, Table 5, page 41 ), the time required for leaf development gradualiy diminished during the winter. The Iow temperature may have been respongible, as Coville has suggested, for the quicker response shown by the buds as the season advanced.

The effect of low temperature upon buds of Allanthus shoots after active growth had been established was disastrous. When shoots were first subjected to the moisturetemperature treatment unt1l the buds developed to the point of breaking and then placed in the refrigerator, they could 
not be forced into further growth by the moisture-temperature treatment but quickly withered and died. A similar frot effect upon the growing buds was observed in the thicket. The apical buds wore growing viborously on the first day of March, 1932 ( see, Plate VII). On the fifth day of the same month the temperature dropped rapidly and rematned uniformly low for a pertod of ten days. During this period temperatures as Iow as - $10^{\circ} \mathrm{c}$ were recorded by the United States Weather Bureau of Louisvilie, Kentucky. 3 on the sixteenth day of April, a tabulation was made of the position of growing buds on a random Bample of 573 shoota ( see, Table 6). The tip bud was found to be growing on only nine of the shoots and the uppermost bud growth found upon the other 564 shoots was as follows: Thirty were developing their second buds; elghtynine were developing their third buds; one hundred fourteen were developing their fourth buds; seventy-three were developIng their fifth buds; fifty-seven were developing their aixth buds; forty-nine were developing their seventh buds; fortyfive were developing their eighth bude; thirty-eight were developing their ninth buds; twenty were developing their eleventh buds; ten were developing their twelf th buds; eleven were developing their thirteenth buds; seven were developing their sixteenth buds; one was developing 1 ts eighteenth bud. Inasmuch as the bud failure found in the thicket, after the unseasonable, sub-freezing temperature corresponds to the

The weather bureau is less than five miles from the Allanthus thicket. 
Table 6

Table 6 shows the arrangement of growing buds found upon 573 Allanthus glandulosa shoots growing in the thicket on the s1xteenth day of April, 1932.

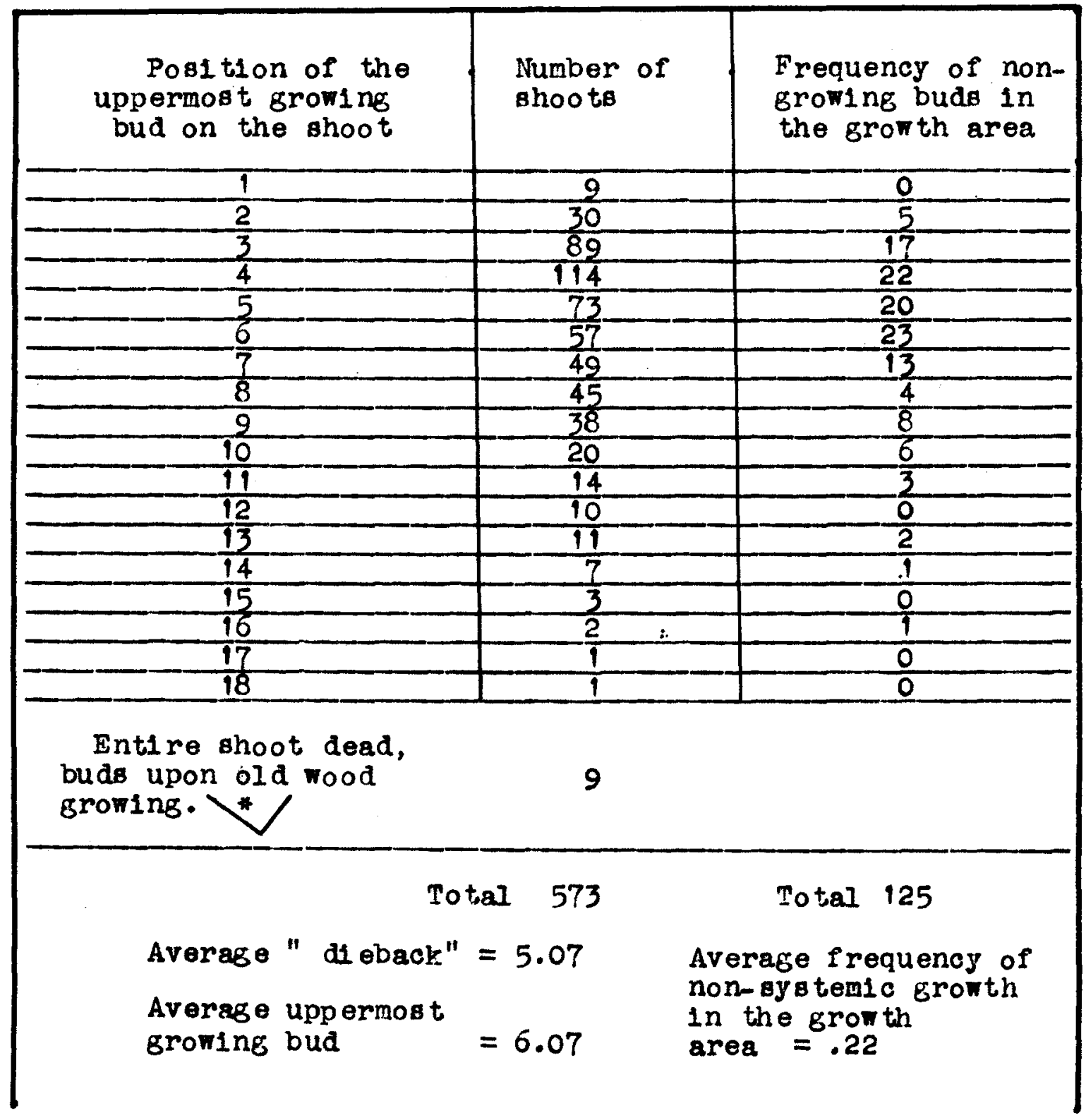

The nine cases of entire fallure were not included in the calculation of averages. 
accelerated aplcal bud development found upon shoots prior to the period of extreme low temperature, it is evident that frost was the effecter of this bud fallure ( see, Plates IX and VII ).

The importance of unseasonable climatic conditions as a factor in affecting branch-patterns in Alanthus glandulose 18 show by the bud growth found in 1932. The shoots used in the temperature-moisture forcing testa were from the same thicket and of the same year's growth as the random sample of Erowine shoots found in the thicket on the sixteenth day of Apri1. The 281 shoots Eathered from the ninth day of November 1931, until the twenty-iifth day or February 1932, and forced to grow, developed $97 \cdot ?$ per cent of their tip buds ( see, Table 3 ). Bud development in these forced cuttings was typically apical ( development was normal as it corresponds to the natural Erow th found upon shoots in the thicket on the first day of March (see, Plate VII). After the subfreezine temperature from the fifth to the fifteenth day of March, the random sample of 573 growing shoots in the thicket on the sixteenth day of April showed tip bud growth in only 1.25 per cent of the shoots ( see, Table 6, page 52). Instead of the ap1cal bud development shown in the cut shoots, the typical bud development found on the trees was below the tip ( IX 1. The averace uppermost bud to develop was the sixth. The range of this bud fallure extended in some instances to the previous season's rood. Nine shoots were found to be 


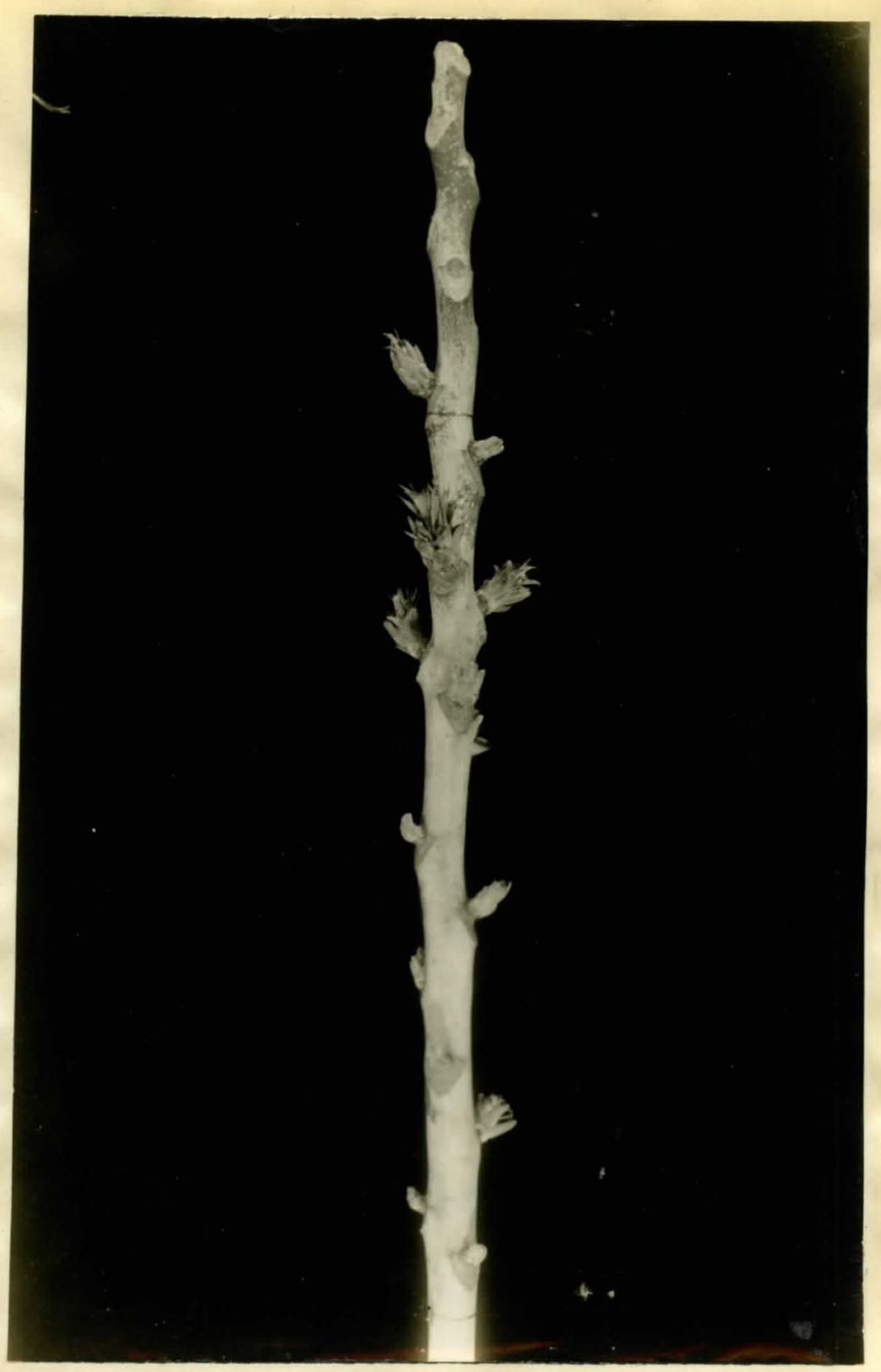

Plate IX

Plate IX shows bud growth found in the thicket on the 81xteenth day of April 1932. The degree of apical bud fallure in this shoot is one bud position greater than the average apical bud fallure found on a random sample of 573 shoots. The unequal rivalry of buds was typl cal. 
dead and buds were developing upon the old wood ( see, Plate $\mathrm{V}-\mathrm{A}$ ). If the bud fallure shown in the cuttings was a fair averace due to immaturity, frost was responsible for an average dying back of 4.95 buds per shoot in the 1932 shoot growth.

The shifting of the growth area caused by the apical bud failure was associated with a change in the arrangement of developing buds upon the parent shoots. The basifugal arrangement of developing buds characteristic in the shoots forced into growth, was affected either directly by the action of the frost upon the buds thenselves or indirectly by the frost in shifting the growth area in the shoots. In the 281 cut shoots forced into growth, there were twelve cases of nonactive buds interposed in the growth area of the shoots ( see, Table 3, page 27), and bud development in these shoots was characteristically apical and basifugal ( VIII ). In the random sample of frost injured shoots in the thicket on the sixteenth day of April, growth vigor did not decline in this baglfugal order ( The average per cent of non-8jratemic growth was approzimately elghteen per cent greater than the averafe found for the 281 shoota cultivated in the laboratory ( see, Table 3, pase 27 and Table 6, pare 52). It was al so observable that the rivalry of buds in shoots was more equal if the growing buds were in the tip area. In those cases where the dying back extended no farther than the first bud, close mivalry of the immediately lower buds wa the rule ( see, Plate XI). When the dying back extended lower on the parent shoot, the rivalry was 


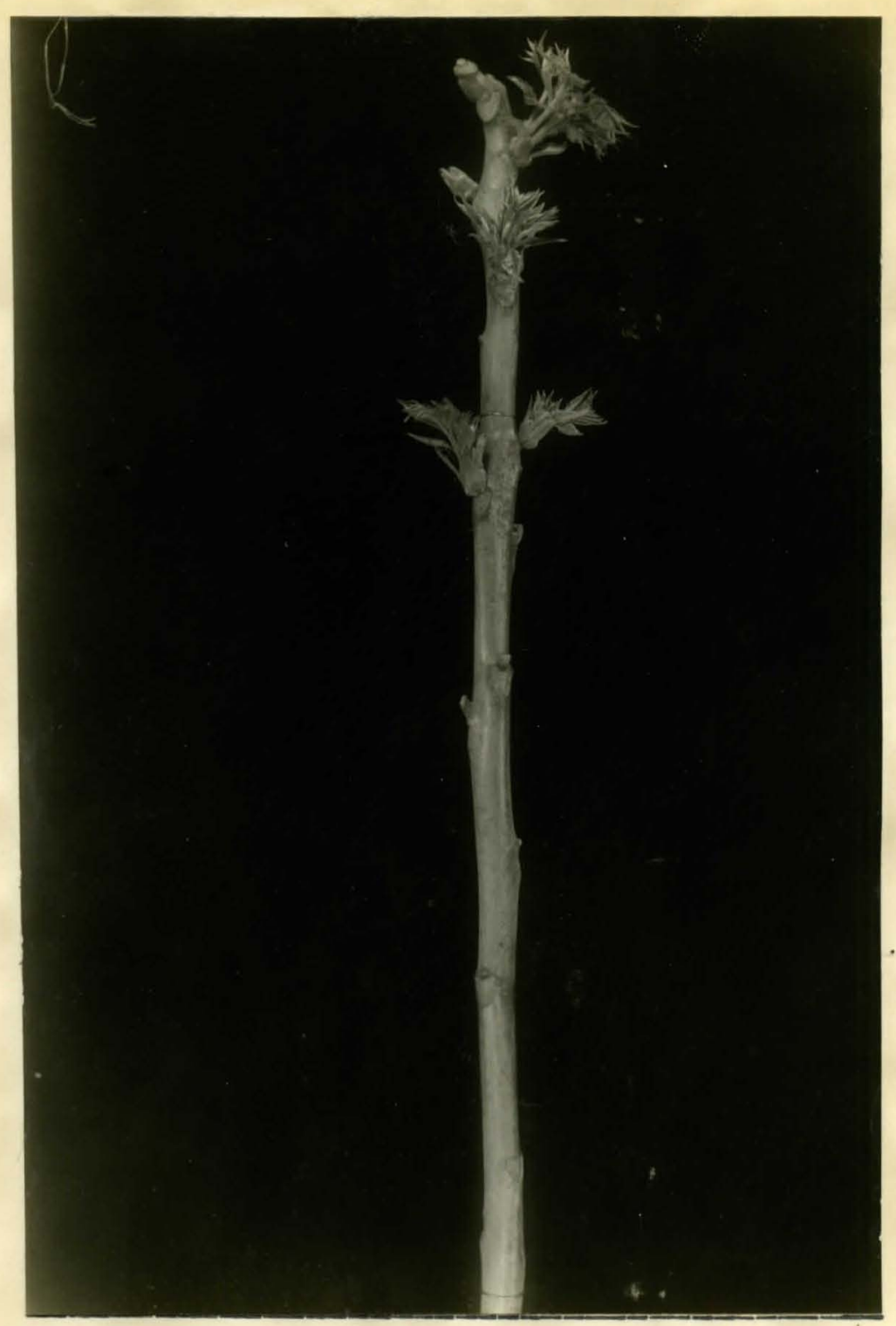

Plate X

Plate $X$ shows the unequal $M$ valry found in the buds of a shoot when the action of frost killed the tip buds and shifted the growing area in the shoot. The photograph was made on the sixteenth day of April, 1932. 


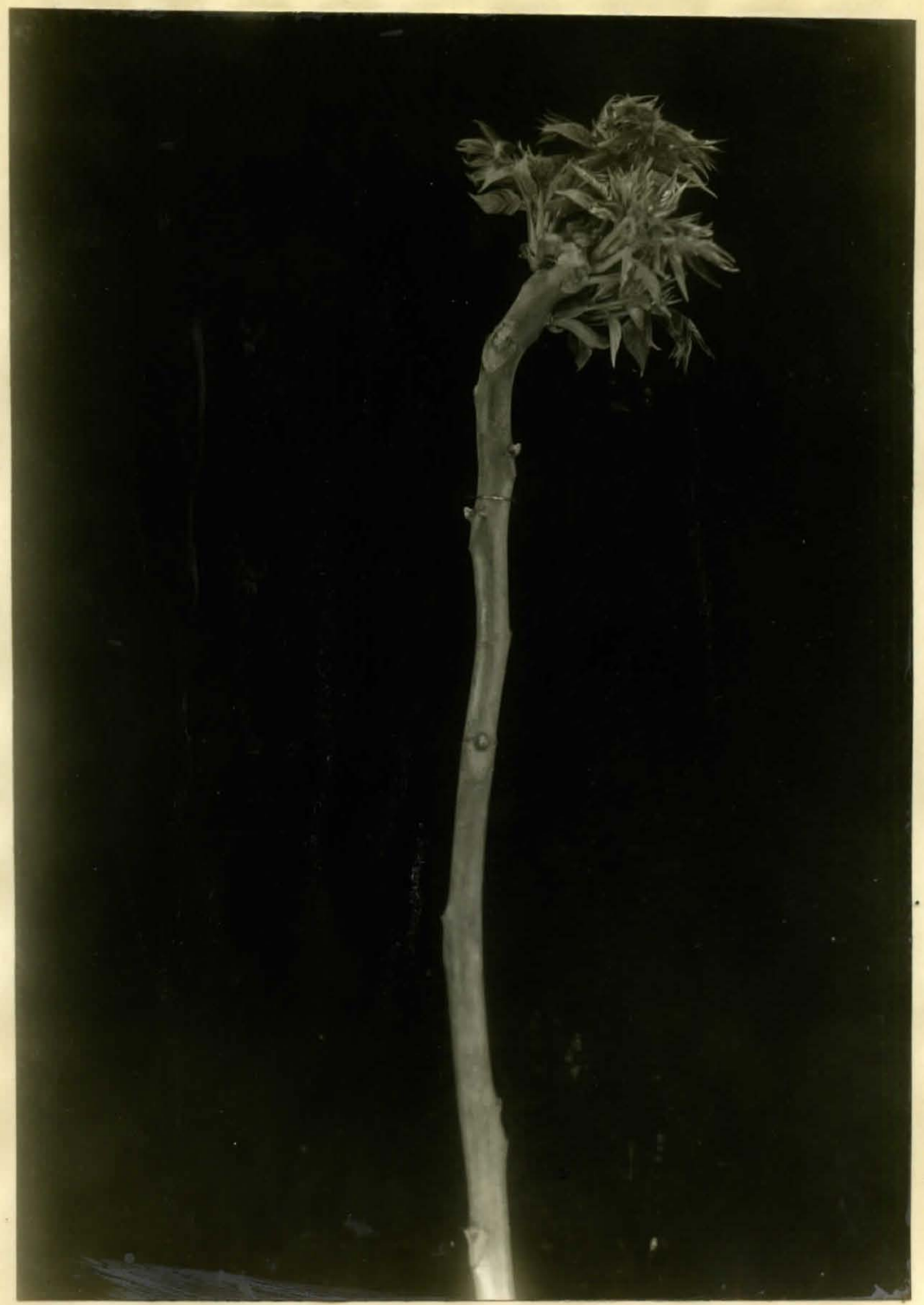

Plate XI

Plate XI shows the typical development of buds in a shoot that had its tip bud killed by frost. The photograph was made on the sixteenth day of April, 1932. 
less equal ( see, Plate $X$ ).

The temperature after the sixteenth day of April was never low enough to seriously hamper bud growth in the tnicket. The rivalry shown between the buds on that date culminated in the development of the successful buds into branches. On the twentietn day of June, new shoot:growth was far enough advanced to show the branch-patterns result-ing from the bud development found on the sixteenth day of April. In general the patterns corresponded with the strongest pud growth shown at the earlier stage of development. The close rivalry shown by the buda near the apex of shoots resulted in the development of branching shoots of Bimilar size ( geee, Plates XI and XII-A). Less equal rivalry shown by lower buds in shoots, where a longer section of the tips was frost killed, resulted in the development of scattered branches ( see, Plates XII-B and XIII). It is, therefore, evident that the principal cause of these branchpatterns was frost. 


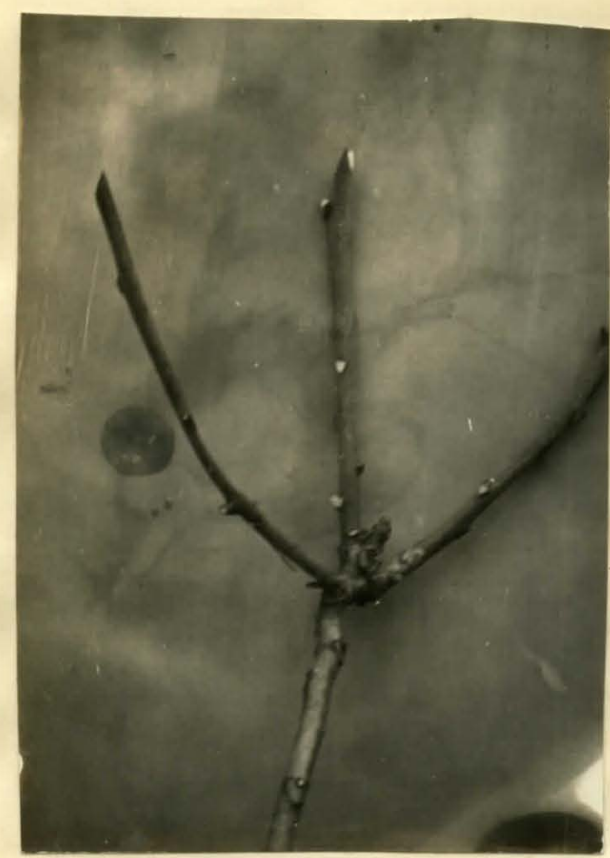

A

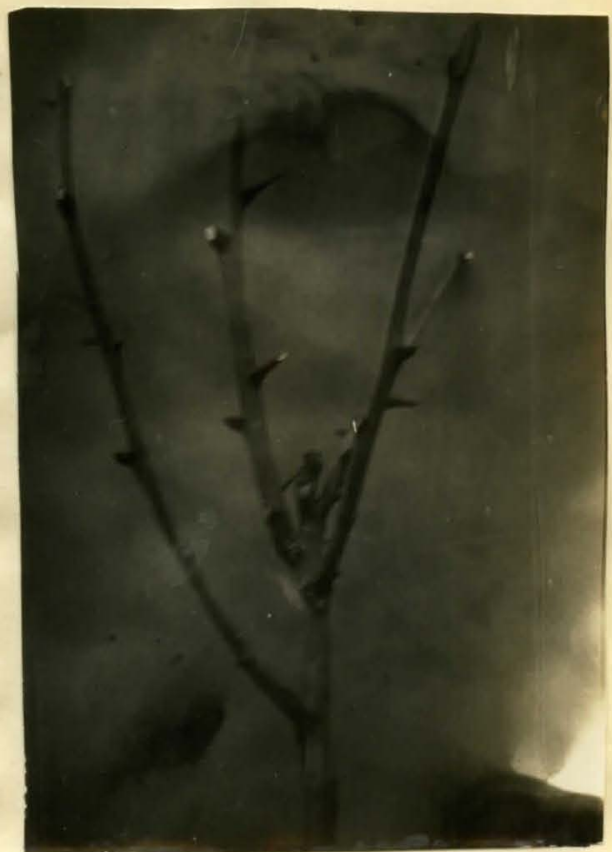

B

Plate XII

Plate XII shows two patterns of branching found in the thicket on the twentieth day of June, 1932.

A. - shows the result of close rivalry in three upper bude.

B. - shows the result of nearlyequal rivalry in four buds. 


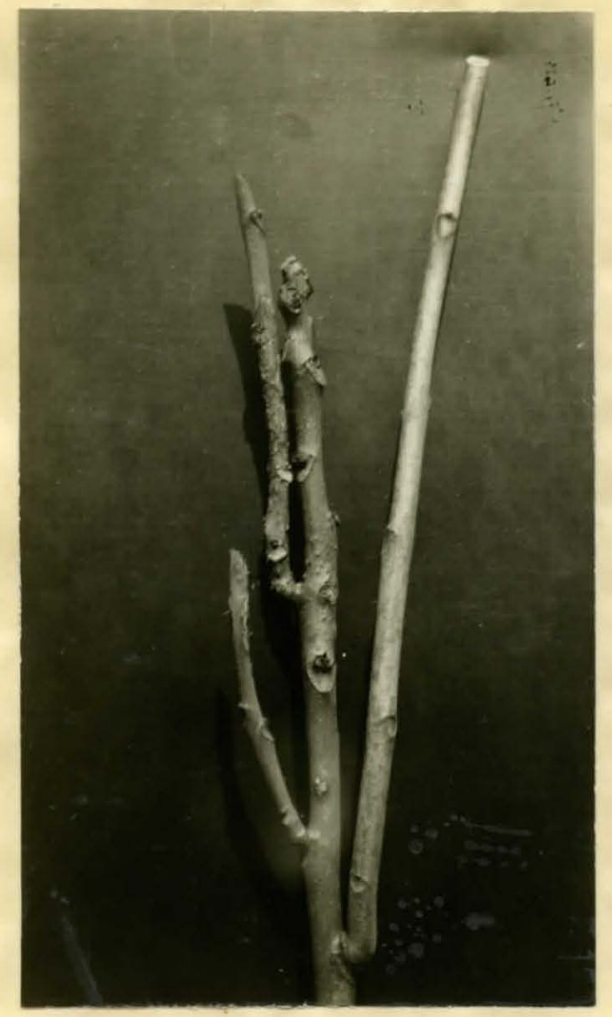

A

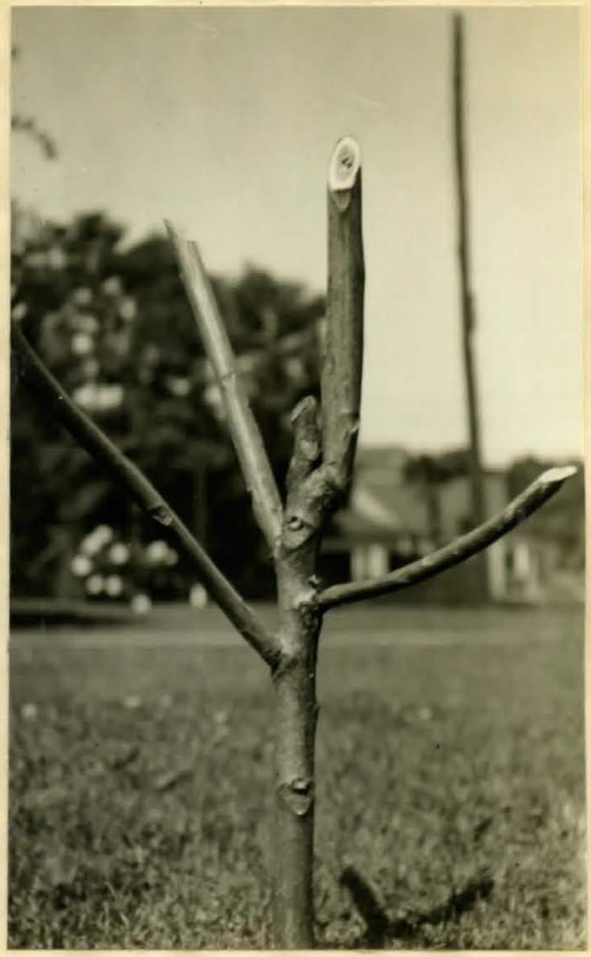

B

Plate XIII

Plate XIII shows two patterns of branching found in the thicket on the twentieth day of June, 1932.

A. - shows a widely scattered pattern of branching.

B. - shows failure of one bud in the active growth-area. 


\section{SUMMARY}

The number and arrangement, of branches developed in Ailanthus shoote in the two successive seasons of 1930 and 1931 varied with the behavior of the most apical bud. Then a branch was established from the apical bud of a shoot, other branch development upon the shoot was infrequent. If other branches were established, the order of their arrangement was basifugal ( gee, Plate II). Then no branch was established from the most apical bud on a shoot, branches developed from lower buds. In this type of branching the average was more than two branches for each shoot ( gee, Table 1, page 14, and Table 2, page 15).

The establishment of branches from tip buds was infrequent. Only 46 in 661 shoots exhibited this type of branching. The average bud position from which uppermost branches were established varied in the two seasons by 4.7 bud positions. The average degree of bud fallure in the shoots of the combined sample was 6.8 for each shoot.

Buds upon cut shoots developed in a basifugal order. The most aplcal bud on the shoot was dominant in 97.7 per cent of the shoots. Immaturity of the tip bud was responsible for the slight failure shown in these buds ( $27)$.

Death of the tip bud or death to the apical part of the shoot resulted in active development of lower buds (see, 
Table 4, page 32 ).

Frost injury caused an average dying back of approximately five buds per shoot in the 1932 growth of shoots. 
CONCLUSION

The principal inherent factor in Ailanthus bud development 18 Itg basifugal habit of growth. The principal external factor conditioning the inherent habit in bud growth is frost. Inasmuch as the position and number of branches developed upon parent shoots was determined by the action of frost in shifting the growth area in shoota, frost is the principal cause of the method of branching in Allanthus glanduloga. 


\section{LITERATURE CITED}

1. Apgar, A. C. 1892 Trees of the northern Unt ted States. p. 76 American Book Co.

2. Bergen, J. Y. 1901 Foundations of botany. p. 69. Ginn and Co.

3. Blakeslee, A. F., and Jarvis, C. D. 1913 Trees in winter. p. 390. The Macmilian Co.

4. Butler, O. R., Smith, T. O., and Curry, B. F. 1917 Physiolozy of the apple. New Hampshire Agr. Exp. Sta. Bull. No. 14.

5. Barker, B. T. F., and Lees, A. H. 1919 Factors governIng fruit-bud formation. Ann. Rept. Hort. Res. Sta. University of Bristol, pp. 85-98.

6. Coville, F. V. 1920 The influence of cold in atimulatine the growth of plants. Jour. Agr. Res. Vol. 29 , pp. $151-267$.

7. Child, C. 14., and Bellamy, A. T. 1920 Physiological 180lation by 1 ow temperature in Bryophrlium calycinum. Bot. Gaz. Vol. 70, pp. 240-260.

8. Daviea, P.A. 1931 Distribution of total nitrogen in regeneration of willow. Bot. Gaz. Vol 41, pp. $320-326$. 


\section{LITERATURE CITED}

9. Denny, F. E., and stanton, E. N. 1928 Chemical treatment for ahortening the rest period of pot-grown woody plants. Amer. Jour. Bot. Vol. 15, pp. 327-336.

10.

1928 Localization of response in woody tissues to chemicals that break the rest period. Amer. Jour. Bot. Vol. 15, pp. 337-345.

11. Eustace, H. J. 1905 Winter injury to fruit trees. New Yl.. (Geneva) Agr. Exp. Sta. Bull. No. 269, pp. 323-343.

12. Farmer, J. B. 1918 on the quanti tative difference in water conductivity of wood in trees and shmabs. Part II. Proc. Royal Society No. 90. pp. 232-250.

13. Garret,t, H. E. 1926 Statistics in psychology and education. pp. 118-220. Longmans, Green and Co.

14. Gardner, F. E. 1925 A study of the conductive tisoues in shoots of Bartlett pear and the relationship of food movement to the dominance of the apical buds. Univ. Calif. Agr. Exp. Sta. Tech. paper No. 20, pp. $22-24$.

15. Harvey, R. B. 1918 Hardenings process in plants and developments from frost injury. Jour. Agr. Res. Vol. 15, pp. 83-111. 


\section{LITERATURE CITED}

16. Howard, W. L. 1915 An experimental study of the rest period in plants. Unt versity of Missourt Agr. Exp. sta. Res. Bull. No. 16, p. 3.

17. Johannsen, T. 1906 Das Aether-Verfahren be1m Fruh= treiben. p. 60 . G. Fisher (Jena).

18. Keeler, H. L. 1900 Our native trees. pp. 36-40. Charles Scribner's Sons.

19. Loeb, J. 1915 Rules and mechanism of inhibition and correlation in the regeneration of Bryophylium calycinum. Bot. Gaz. Vol. 60 , pp. 247-276.

20. Roberts, R. H. 1922 The development and winter injury of cherry blossom buds. University of Fisconsin Agr. Exp. Sta. Bull. No. 52, pp. 1-24.

21. Reed, H. S., and Halm, F. F. 1919 on the existence of a growth inhibiting substance in the Chinese lemon. Univ. Calif. Pub. ACr. So1. Vol. 4, pp. 9g-112.

22. Summers, F. 1924 Factors governing bud formation. New Phy tologist Reprint No. 14, p. 66.

23. Wiggans, C. C. 1919 Progressive report on horticultural Investigations. Mssouri Agr. Exp. Sta. Bull. No. 163, pp. 55-62. 